Review

\title{
The Many Faces of C/EBP $\delta$ and their Relevance for Inflammation and Cancer
}

\author{
Kuppusamy Balamurugan and Esta Sterneck ${ }^{凶}$ \\ Laboratory of Cell and Developmental Signaling, Center for Cancer Research, National Cancer Institute, Frederick, MD-21702-1201, U.S.A. \\ $\bowtie$ Corresponding author: Email: sternecg@mail.nih.gov Phone: +1-301-846-1471; Fax: +1-301-846-1666.
}

() Ivyspring International Publisher. This is an open-access article distributed under the terms of the Creative Commons License (http://creativecommons.org/ licenses/by-nc-nd/3.0/). Reproduction is permitted for personal, noncommercial use, provided that the article is in whole, unmodified, and properly cited.

Received: 2013.07.22; Accepted: 2013.08.27; Published: 2013.09.20

\begin{abstract}
The CCAAT/enhancer binding protein delta (CEBPD, C/EBPS) is a transcription factor that modulates many biological processes including cell differentiation, motility, growth arrest, proliferation, and cell death. The diversity of C/EBP $\delta$ 's functions depends in part on the cell type and cellular context and can have opposing outcomes. For example, C/EBP $\delta$ promotes inflammatory signaling, but it can also inhibit pro-inflammatory pathways, and in a mouse model of mammary tumorigenesis, C/EBP $\delta$ reduces tumor incidence but promotes tumor metastasis. This review highlights the multifaceted nature of C/EBPS's functions, with an emphasis on pathways that are relevant for cancer and inflammation, and illustrates how C/EBP $\delta$ emerged from the shadow of its family members as a fascinating "jack of all trades." Our current knowledge on C/EBP $\delta$ indicates that, rather than being essential for a specific cellular process, C/EBP $\delta$ helps to interpret a variety of cues in a cell-type and context-dependent manner, to adjust cellular functions to specific situations. Therefore, insights into the roles and mechanisms of C/EBP $\delta$ signaling can lead to a better understanding of how the integration of different signaling pathways dictates normal and pathological cell functions and physiology.
\end{abstract}

Key words: C/EBP, transcription factor, cell signaling, inflammation, cancer.

\section{Introduction}

The CEBPD gene encoding the C/EBP 8 protein, a member of the C/EBP transcription factor family, was cloned by sequence homology more than 20 years ago. Several reviews have been written about the C/EBP family and have emphasized other C/EBP proteins [1-6]. This article will focus specifically on C/EBPS. Initially, C/EBP $\delta$ was mostly used as a marker for adipocyte or myeloid differentiation and of inflammatory activation. Early work on C/EBP $\delta$ was conducted primarily in cell lines and attributed a variety of functions to C/EBP $\delta$ that were not necessarily fully supported by studies in vivo. For example, C/EBPS is not essential for adipocyte or myeloid differentiation in mice. Intriguingly, studies of C/EBP $\delta$ in different systems have led to it being labeled as a "tumor suppressor" or also as a tumor-promoting "mesenchymal master regulator" [7, 8]. From these seeming contradictions, and from more recent studies using Cebpd knockout mice, it has become apparent that C/EBP $\delta$ in fact functions as a modulator of many processes. This review summarizes and attempts to integrate some of our current knowledge about C/EBPS, with an emphasis on findings that have relevance for cancer biology and inflammatory signaling.

Normal cellular functions occur through the orchestrated temporal and spatial interactions of molecules, whose roles have evolved and been selected for over millions of years. Genetic mutations and epigenetic changes that disturb these interactions may result in dedifferentiation, loss of growth control, or escape from cell death mechanisms, and eventually lead to cancer. Most cancer-related deaths are due to metastatic disease, which is the result of a series of complex steps in which malignant cells disseminate from the primary tumor and begin to establish growth in other organs [9]. It is also now apparent that most cancers can thrive only by corrupting the normal host 
environment, at both the cellular microenvironment and systemic levels [10].

Proteins whose aberrant activity can drive tumor development are termed oncogenes. Proteins whose normal activity primarily inhibits tumor development have been termed tumor suppressors. However, since the emergence of the "TGF- $\beta$ paradox" $[11,12]$, it has become ever more clear that this nomenclature is often inaccurate or, at best, incomplete, and that this limitation in conceptualizing protein functions applies not only to cancer but to most paradigms in cell and organismal biology. Indeed, such labels can hinder our appreciation of the full complexity of molecular functions and of the diversity of molecular interactions that underlie the great variety of cellular and physiological outcomes. Our current knowledge of C/EBP $\delta$ suggests that it is one of the molecules that defy labeling, because it takes on multiple, context-dependent functions. The detailed study of such molecules presents an opportunity to gain deeper insights into the diversity and complexities of signaling pathways and their adaptations that govern normal and pathological conditions.

\section{C/EBPS as a versatile modulator of gene transcription}

The C/EBP family of transcription factors is defined by a highly homologous basic region-leucine zipper (bZIP) domain that mediates its dimerization and DNA binding. C/EBP $\delta$ is encoded by the single-exon $C E B P D$ gene, and only one full-length protein isoform is known to date. C/EBP factors can bind DNA only as dimers by virtue of the leucine zipper scissors' grip mechanism [1]. C/EBPS's confirmed heterodimerization partners consist of all the other $\mathrm{C} / \mathrm{EBP}$ proteins, including $\mathrm{C} / \mathrm{EBP} \zeta / \mathrm{CHOP}$ as well as ATF4 [13]. However, the specific roles of such heterodimeric interactions in $\mathrm{C} / \mathrm{EBP} \delta^{\prime}$ 's physiological functions are completely unknown. Interestingly, both CHOP and the ATFs are stress response factors, with well-characterized roles in hypoxia and the unfolded protein response [14]. These proteins are prime candidates for physiological heterodimer formation with $\mathrm{C} / \mathrm{EBP}$, especially under hypoxia (see section below). This notion awaits further investigation.

C/EBP proteins exhibit largely identical DNA-binding specificities, at least in vitro $[2,13,15]$. Therefore, it is impossible to predict from DNA sequences which C/EBP member may target a particular gene. For example, the aromatase promoter is activated by C/EBP $\beta$ but not by C/EBPS in human adipose fibroblasts [16]. Furthermore, target gene regulation may also depend on interactions with other regulatory factors. The prolactin gene promoter is repressed by $\mathrm{C} / \mathrm{EBP} \delta$ and activated by $\mathrm{C} / \mathrm{EBPa}$, in each case through interaction with Pit-1 [17, 18]. Comprehensive surveys of C/EBPS's target genes by chromatin immunoprecipitation (ChIP) followed by subsequent validation using cells with C/EBPS knockdown or knockout have been reported for a mouse mammary epithelial cell line [19], human keratinocytes [20], and mouse macrophages [21]. In addition, C/EBPS ChIP data from K562 and HepG2 cells are now available from the ENCODE project (encodeproject.org).

$\mathrm{C} / \mathrm{EBP} \delta$ has a bona fide transcription transactivation domain [1], and most of C/EBP $\delta$ 's target gene promoters are activated by it [19-21]. Figure 1 illustrates $\mathrm{C} / \mathrm{EBP} \delta$ 's protein structure, highlights its protein interactions that have been confirmed with endogenous proteins, and shows the amino acids that are required for functional modifications. Target gene transactivation can be achieved by C/EBP $\delta$ 's interaction with the CBP co-activator: that is, C/EBP $\delta$ triggers CBP phosphorylation, which depends on residues Leu81 and Phe82 on C/EBPS [22]. However, $\mathrm{C} / \mathrm{EBP} \delta$ can also inhibit gene expression, depending in part on its protein modification or selective protein interactions. Sumoylation of $\mathrm{C} / \mathrm{EBP} \delta$, which requires its K120 residue, abolishes its interaction with the $\mathrm{CBP} / \mathrm{p} 300$ co-activator, and may be one mechanism by which C/EBPS becomes a transcription repressor instead of an activator [23]. The K120 residue is also required for the acetylation of C/EBPS by p300/CBP in vitro and may contribute to target gene transactivation $[23,24]$.

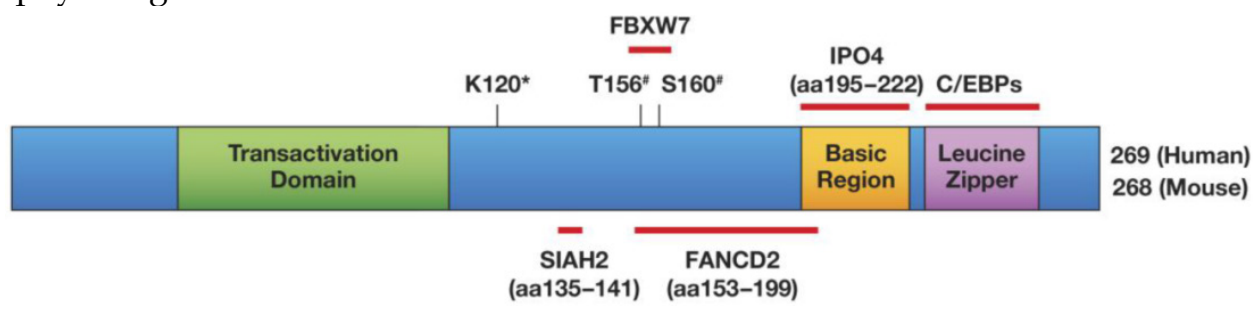

Fig I. Schematic of the C/EBPס protein, and mapped modifications and interactions. Only interactors that have been mapped to a sub-domain of C/EBPס and whose interactions were confirmed at the level of endogenous proteins have been included in this Figure: SIAH2 [56] , FBXW7 [57], FANCD2 [4I], IPO4 [4I]. Amino acids (aa) that are important for protein modifications are indicated: \#phosphorylation by GSK-3 3 ; *K 120 is necessary for acetylation and sumoylation [23] and for ubiquitination by SIAH2 [56] but not by SCFFBXW7 [57]. KI 20 was not confirmed as the acceptor site for these modifications. Transactivation Domain: aa 4 I-I08 [60, I78] Basic Region/Leucine Zipper: aa 195-222/226-254 [6]. 
The physical interaction of C/EBPס with SP1 [25] or ZNF638 [26] leads to synergistic gene activation, whereas C/EBPS's interactions with Rad [27] or DIPA [28] inhibit the activation of target genes. C/EBPS represses the expression of IGF-1 in osteoblasts [29], CD-RAP in chondrocytes [30], apoC-III in hepatoma cells [31, 32], manganese superoxide dismutase [33], and FBXW7a [34]. C/EBP $\delta^{\prime}$ s interaction with HDAC1 contributes to the repression of the haptoglobin [35] and of the PPARY (PPARG) promoter [36], whereas its interaction with FOXO3a activates PPARY expression [37]. C/EBP $\delta$ 's association with GATA4 [38] or Runx 2 [39] can modulate target gene activation versus repression. Furthermore, its interaction with SMAD3 inhibits the DNA-binding function of $C / E B P \delta$, which may be part of the mechanism by which TGF- $\beta$ inhibits adipocyte differentiation [40]. Although far from complete, the diverse effects illustrated in the above list suggest that almost anything can result from $\mathrm{C} / \mathrm{EBP} \delta$ binding to a target promoter. Furthermore, a non-transcriptional function for $\mathrm{C} / \mathrm{EBP} \delta$ has also been discovered: it chaperones the FANCD2 DNA repair protein into the nucleus [41]. FANCD2 has also been shown to interact with the transcription factor NFKB and to inhibit as well as activate gene expression [42, 43]. Therefore, it is quite plausible that FANCD2 also modulates target gene regulation by $\mathrm{C} / \mathrm{EBP} \delta$, in addition to the role of their interaction in nuclear translocation of FANCD2.

Most of the above-mentioned data were generated in cultured cell lines. Insights into physiologically relevant functions have been derived from mice with a null mutation of the Cebpd gene. Analysis of Cebpd knockout $(\mathrm{KO})$ mice revealed that the protein is not essential for normal development or the adult life of mice in a pathogen-free environment $[44,45]$. This is consistent with $\mathrm{C} / \mathrm{EBP}^{\prime}$ 's expression being low to undetectable in most organs and cell types. However, $\mathrm{C} / \mathrm{EBP} \delta$ expression is rapidly but transiently induced by a variety of stimuli $[1,6]$, which may be indicative of C/EBPS's function as a modulator for specific physiological adaptations. Table 1 summarizes the phenotypes that have been characterized in Cebpd null mice to date.

\section{Regulation of C/EBPס expression and activity}

As mentioned above, C/EBP $\delta$ expression is typically low to undetectable. However, a number of extracellular signals, including cytokines, bacterial lipopolysaccharide (LPS), and corticosteroid, can induce it, suggesting that $\mathrm{C} / \mathrm{EBP} \delta$ has a role in stress responses [6]. Hypoxia also induces C/EBP $\delta$ in cultures of various cell types, and in certain tissues, including brain and tumors [7, 34, 47, 48]. Table 2 summarizes some of the reports on the regulation of C/EBP $\delta$ expression, and highlights cases in which inflammatory regulators and hormones induce its expression. In addition, Runx factors have been described as either activating or inhibiting the CEBPD promoter activity $[39,49]$. Finally, C/EBPS can activate its own gene expression $[1,21]$.

Induced C/EBPS expression is typically transient. In macrophages, LPS induces CEBPD through NFKB , which is subsequently silenced by ATF3 [21]. This feedback loop does not exist in kidney fibroblasts, where CEBPD is induced through c-Jun and maintained by a mechanism requiring IRAK-1 [50]. Interestingly, the histone deacetylase inhibitor trichostatin A interrupts c-Jun's binding to SP-1 and the Cebpd promoter, and prevents LPS-induced C/EBPס expression in RAW264.7 macrophages [51]. Thus, $C E B P D$ expression can also be modulated through modification of the c-Jun protein. In keratinocytes, $C E B P D$ gene expression is inhibited by $\triangle N p 63 a$, while C/EBPS augments $\triangle \mathrm{Np} 63 \mathrm{a}$ expression, providing a mechanism for the transient C/EBPS induction during differentiation [52]. The transient nature of C/EBPS expression hints that persistently elevated C/EBPS levels might lead to an adverse outcome. This concept will be discussed in more detail below, in the section on Inflammation.

At the level of mRNA stability, C/EBPS expression can be increased by the binding of HuR to its 3'UTR. This mechanism can be activated by UV radiation through p38MAPK, and by prostaglandin E2 $\left(\mathrm{PGE}_{2}\right)$, which trigger the nuclear to cytoplasmic translocation of HuR [53, 54]. Ectopic microRNA let-7c downregulates the CEBPD mRNA level in macrophages by a mechanism that requires the $3^{\prime} \mathrm{UTR}$, which suggests that the CEBPD mRNA is directly targeted by let-7c [55].

At the level of protein stability, C/EBPS is downregulated by the SIAH2 E3 ubiquitin ligase [56] and the SCF-FBXW7a polyubiquitination complex [57]. SIAH2 can act as an oncogene [58], while FBXW7a is a tumor suppressor in epithelial cancers [59]. Hence, two potentially antagonizing pathways both downregulate C/EBPS expression. In turn, C/EBP $\delta$ inhibits the expression of FBXW7a [34], resulting in a negative feedback loop [57]. The degradation of C/EBP $\delta$ by FBXW7 depends on C/EBPS's prior phosphorylation on threonine T156 (and possibly serine S160) by GSK-3 $\beta$ kinase. C/EBP $\delta$ is therefore stabilized by signals that inhibit GSK-3 $\beta$ activity, such as TLR4 activation [57]. 
Table I: Summary of C/EBPס knockout mouse phenotypes. Only reports with in vivo studies (i.e., not those using only cultured cells) are included.

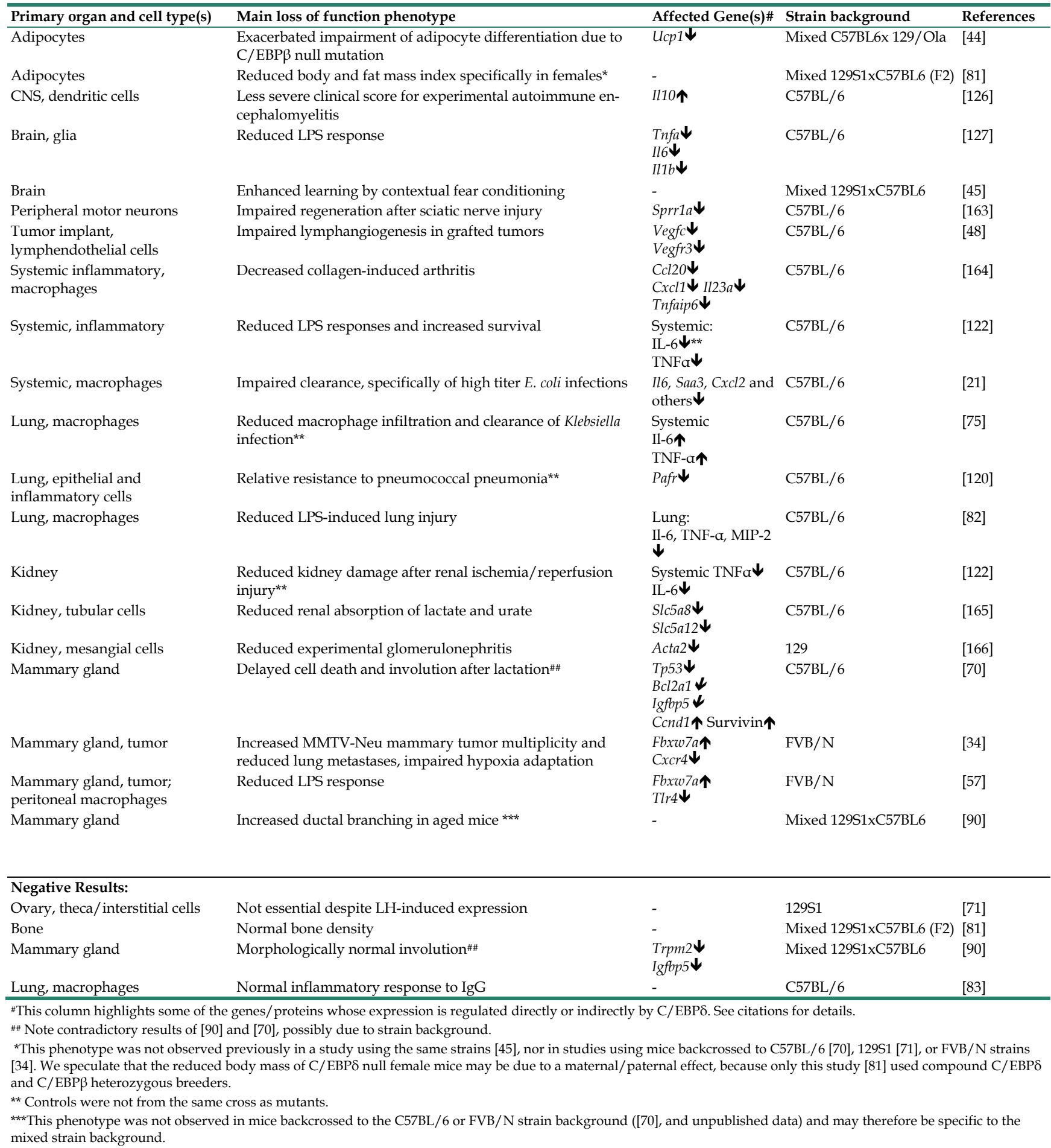


Table 2: Regulation of C/EBPס expression: Compilation of some reports describing activators or inhibitors of C/EBPD expression at the RNA and/or protein level. See text for additional examples and further discussion. Exogenous Agent: Experimental treatments. Mediator(s): Molecules that regulate C/EBPD expression directly or indirectly by pharmacological inhibition/activation, overexpression, RNA interference, or gene deletion. Parentheses indicate inferred mediators. Cell type(s): Predominant cell type used in the cited studies ( $h$, human; m, mouse; $r$, rat; MEF, mouse embryo fibroblast; VSMCs, vascular smooth muscle cells). Associated Process: Cellular response to agent/mediator(s) whether functional relevance for C/EBPD in that process was demonstrated or not. Reference(s): Examples are given with preference for most recent publications, as earlier literature on the subject is typically discussed in these papers.

\begin{tabular}{|c|c|c|c|c|}
\hline Exogenous Agent & Mediator(s) & Cell type(s) & Associated Process & References \\
\hline \multicolumn{5}{|c|}{ Induction of C/EBPS expression } \\
\hline EGF & MAPK, CREB & A431 epidermoid carcinoma (h) & Growth Arrest & [167] \\
\hline Hypoxia & HIF-1 & lymphendothelial cells (h) & Lymphangiogenesis & [48] \\
\hline LPS & NFkB (REL) & Bone marrow-derived macrophages $(\mathrm{m})$ & Inflammatory signaling & [21] \\
\hline LPS & IRAK1, AP-1 & Kidney fibroblasts (m) & Chronic inflammation & {$[50]$} \\
\hline LPS & IRAK1, IKKع (IKBKE) & $\begin{array}{l}\text { Bone marrow-derived macrophages }(\mathrm{m}), \mathrm{MEF} \\
(\mathrm{m})\end{array}$ & Inflammatory signaling & {$[61,118]$} \\
\hline Testosterone & & CWR22 prostate cancer cells & Proliferation/progression & [94] \\
\hline Testosterone (DHT) & Androgen receptor & Rv1 and R1 prostate cancer cell lines (h) & ? & [168] \\
\hline Progesterone & Progesterone receptor B & MDA-MB-231 breast tumor cells (h) & Inhibition of proliferation & [169] \\
\hline Dexamethasone & Glucocorticoid receptor & $\begin{array}{l}\mathrm{C}_{2} \mathrm{C}_{12} \text { myotubes, muscle }(\mathrm{m}) ; \\
\text { A549 lung epithelial cells }(\mathrm{h})\end{array}$ & $\begin{array}{l}\text { Muscle atrophy; glucocorticoid } \\
\text { response }\end{array}$ & $\begin{array}{l}{[132]} \\
{[131]}\end{array}$ \\
\hline IL-1 & JNK, CK2, p50/p65 NFKB & Hep3B hepatoma (h) & Inflammatory signaling & {$[170]$} \\
\hline IL- $1 \beta+$ IFN- $\gamma$ & STAT1 & INS-1E insulinoma cells (r) & Inflammation, cell death & [112] \\
\hline IL-6 & STAT3, SP1 & HepG2 hepatoma cell line (h) & (Inflammatory signaling) & {$[171]$} \\
\hline IL-6 & STAT3 & LNCaP prostate cancer cells (h) & Growth arrest & [92] \\
\hline Oncostatin M & JAK2/STAT3 & HC11 mammary epithelial cells (m) & Growth arrest & [88] \\
\hline \multirow[t]{2}{*}{ Insulin } & PI3K & VSMC & Proinflammatory gene expression & [172] \\
\hline & Runx2 & Osteoblasts (r) & Proliferation & [39] \\
\hline cAMP & Mdm2/CREB/Crtc2 & MEF & Adipogenesis & [173] \\
\hline $\begin{array}{l}\text { Vasoactive intestinal pep- } \\
\text { tide, pituitary adenylate } \\
\text { cyclase activating protein, } \\
\text { noradrenalin, }\end{array}$ & (cAMP) & Cortical astrocytes (m) & Glycogen synthesis & {$[174]$} \\
\hline $\begin{array}{l}\text { 1-(2-hydroxy-5-methylphen } \\
\text { yl)-3-phenyl-1,3-propanedio } \\
\text { ne (HMDB) }\end{array}$ & p38, CREB & $\begin{array}{l}\text { A431 (epidermoid) and HeLa (cervical) carci- } \\
\text { noma cell lines (h) }\end{array}$ & Cell death & [99] \\
\hline 1,25-Dihydroxyvitamin D3 & (VDR) & $\begin{array}{l}\text { LNCaP prostate cancer cells; MCF-7, T47D } \\
\text { breast cancer cells }(\mathrm{h})\end{array}$ & Growth inhibition & [93] \\
\hline \multicolumn{5}{|c|}{ 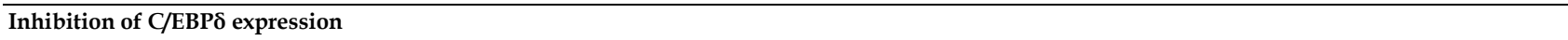 } \\
\hline M-CSF & Let-7c & Bone marrow-derived macrophages $(\mathrm{m})$ & M2 polarization & [55] \\
\hline \multirow[t]{2}{*}{ Src (family) kinase } & SIAH2 & Breast tumor cell lines $(\mathrm{h})$ & $\begin{array}{l}\text { C/EBPS degradation, "transfor- } \\
\text { mation" }\end{array}$ & [56] \\
\hline & GSK3 $\beta$, FBXW7a & Peritoneal macrophages & $\begin{array}{l}\text { C/EBPS degradation, inhibition of } \\
\text { LPS- response }\end{array}$ & [57] \\
\hline Hsp70 & TLR2, IL-10 & Bone marrow-derived dendritic cells & Anti-inflammatory & [175] \\
\hline LPS & ATF3 & Bone marrow-derived macrophages $(\mathrm{m})$ & $\begin{array}{l}\text { Feed-back inhibition of inflamma- } \\
\text { tory signaling }\end{array}$ & [21] \\
\hline \multirow[t]{2}{*}{ LPS, TNFa } & $\operatorname{Miz1}(\mathrm{pS} 178)$ & $\begin{array}{l}\text { Lung tissue and MLE-12 lung epithelial cells } \\
(\mathrm{m})\end{array}$ & $\begin{array}{l}\text { Attenuation/inhibition of inflam- } \\
\text { matory signaling }\end{array}$ & [135] \\
\hline & Myc/Max/Miz1 & HC11 mammary epithelial cells (m) & (proliferation) & [134] \\
\hline Chrysin (Flavonoid) & $?$ & $\begin{array}{l}\text { Embryonic cortical neurons, microglia cultures } \\
(\mathrm{m}), \mathrm{BV} 2 \text { microglial cell line }(\mathrm{m})\end{array}$ & Inhibition of inflammation & [128] \\
\hline Troglitazone & $\begin{array}{l}\text { Inhibition of STAT3 by } \\
\text { PPARY }\end{array}$ & VSMCs & Inhibition of IL-1 $\beta$ response & [136] \\
\hline \multirow[t]{3}{*}{ TGF- $\beta$} & $?$ & VSMC & $\begin{array}{l}\text { Inhibition of IL-1 } \beta \text {-induced expres- } \\
\text { sion }\end{array}$ & [162] \\
\hline & SUZ12/YY1 & $\begin{array}{l}\text { A431 (epidermoid) and HeLa (cervical) carci- } \\
\text { noma cell lines (h) }\end{array}$ & (proliferation, tumor progression) & [142] \\
\hline & $\Delta \mathrm{Np} 63 \mathrm{a}$ & HaCaT cells and primary keratinocytes $(\mathrm{h})$ & Keratinocyte differentiation & [52] \\
\hline Pref-1 & Sox9 & MEF, 3T3-L1 pre-adipocytes & $\begin{array}{l}\text { Inhibition of adipocyte differentia- } \\
\text { tion }\end{array}$ & [176] \\
\hline Tunicamycin & IREa & Liver, hepatocytes & $\begin{array}{l}\text { Unfolded protein response, pre- } \\
\text { vention of steatosis }\end{array}$ & [177] \\
\hline Testosterone & (indirect) & Prostate tissue (r) & (tissue maintenance) & [94] \\
\hline
\end{tabular}


Although no other phosphorylation sites on $\mathrm{C} / \mathrm{EBP} \delta$ have been mapped to date, several additional reports point to a role of phosphorylation in the regulation of C/EBPS activity. The serine residue S191 in the extended basic region of $\mathrm{C} / \mathrm{EBP} \delta$ is necessary for the $\mathrm{PGE}_{2}$-mediated activation of $\mathrm{C} / \mathrm{EBP} \delta$ in osteoblasts, although the kinase has not been identified, and S191 has not been confirmed as a phosphorylation site [60]. IL-1 treatment of HepG2 cells induces the tyrosine-phosphorylation of C/EBPS [32], Casein Kinase II phosphorylates C/EBP $\delta$ in vitro [15], and $\mathrm{IKKi} / \mathrm{IKK} \varepsilon$ (IKBKE) is essential for the LPS-induced phosphorylation of C/EBPS [61]. In all cases, the phosphorylation events stimulated C/EBP $\delta^{\prime} s$ DNA-binding activity [15, 32, 61]. Experiments with phsophatase inhibitors also support that $\mathrm{C} / \mathrm{EBP} \delta$ needs to be phosphorylated to bind DNA [62]. Future investigations will have to unravel how IL-1, LPS, CaKII, IKBKE, and also GSK-3 $\beta$ intersect to regulate the $\mathrm{C} / \mathrm{EBP \delta}$ pathway. In addition to phosphorylation, the $\mathrm{C} / \mathrm{EBP \delta}$ protein can be modified by acetylation and sumoylation. These modifications require an intact K120 lysine residue, and, as mentioned above, serve to switch its transactivator function on or off [23]. Interestingly, the same K120 lysine residue is also required for the ubiquitination and degradation of C/EBPS by SIAH2 [56].

By virtue of nuclear localization signals in its DNA-binding domain, C/EBPS is primarily a nuclear protein, which is translocated at least in part by the IPO4 importin [41]. However, C/EBPS's nuclear localization can be regulated. For example, TNF-a not only induces C/EBPS expression, but also promotes its nuclear accumulation in the adult rat hepatocyte cell line RALA255-10G [63]. C/EBPס's nuclear translocation is augmented by the DNA-damaging agent mitomycin C [41]. Billiard et al. demonstrated that a flag-tagged C/EBPS protein is constitutively nuclear in rat calvarial osteoblasts, but the endogenous protein is cytoplasmic in the absence of $\mathrm{PGE}_{2}$ [64]. This last report highlights the potential for misconstruing physiological roles by relying too heavily on overexpression studies.

$\mathrm{C} / \mathrm{EBP} \delta$ constitutively resides in the nucleus of primary vascular smooth muscle cells (VSMCs) from the hypertensive rat, but not in those from normal rats [65]. In VSMCs, IL-1 $\beta$ triggers the relocation of $\mathrm{C} / \mathrm{EBP} \delta$ from its perinuclear localization to the nucleus [66]. The perinuclear localization of C/EBPS has also been observed in a mammary epithelial cell line ectopically expressing the SUMO E3 ligase PIASy [67]. In differentiating adipocytes, during the clonal expansion phase, $\mathrm{C} / \mathrm{EBP \delta}$ localizes to the centromere when cells enter the $S$ phase [68]. Thus, C/EBPS's activity can be regulated at several levels by the modulation of its subcellular localization. However, the mechanistic details of these pathways and/or their physiological relevance remain to be determined.

Nuclear localization is not equivalent with activity. In a cell culture model of adipocyte differentiation, the DNA-binding activity of C/EBPS is delayed compared to its induced expression [68]. In human primary osteoblasts, cytoplasmic PKA is necessary for the nuclear localization of $\mathrm{C} / \mathrm{EBP} \delta$, while further activation of $\mathrm{C} / \mathrm{EBP} \delta$ requires nuclear PKA to mediate $\mathrm{PGE}_{2}$-induced IGF-1 promoter transactivation. However, PKA does not phosphorylate C/EBPS in vitro, suggesting that the mechanism may be indirect [69].

Analyses of C/EBP $\delta$ expression in tissues have so far highlighted its primarily nuclear localization, which has been reported in the involuting mouse mammary gland [70], hypoxic/necrotic areas of mouse mammary tumors and human glioblastoma [7, 34], theca/interstitial cells of the mouse ovary [71], human breast epithelial cells [72], meningioma tumor cells [73], and lung bronchial epithelial and alveolar type II cells [74, 75]. However, even when specific, diffuse immunohistochemical staining in the cytoplasm can be difficult to distinguish from background, leaving open the possibility that $\mathrm{C} / \mathrm{EBP} \delta$ is more widely expressed in the cytoplasm than is currently recognized.

To conclude, much remains to be learned about how the various signaling pathways that regulate $\mathrm{C} / \mathrm{EBP \delta}$ expression and activity at different levels and through subcellular localization are integrated to control C/EBPS's functions and target gene responses.

\section{Integration of C/EBPס signaling with other C/EBP family members}

All five members of the C/EBP family can heterodimerize [13] and therefore could give rise to 15 different dimers with potentially unique or also redundant functions. The existence of several isoforms of $\mathrm{C} / \mathrm{EBPa}, \mathrm{C} / \mathrm{EBP} \beta$ and $\mathrm{C} / \mathrm{EBP \varepsilon}$ [1] may lead to even greater complexity. If and how this diversity is realized in nature is largely unknown. While many studies have described either synergistic or antagonistic regulation of expression of certain C/EBP family members, few have explored the functional consequences of such expression patterns. All full-length C/EBP proteins have been largely associated with growth arrest and differentiation functions [76]. However, these can be cell type-specific and exceptions exist, especially when considering different 
isoforms of the same protein $[3,4,76]$. The subsequent sections will present examples for C/EBPS that highlight its multifaceted nature.

As mentioned above, certain gene promoters may be regulated differentially by specific C/EBP factors in cultured cells. However, the in vivo relevance of these observations has not been established. Most compellingly, gene replacement studies in mice have illustrated that $\mathrm{C} / \mathrm{EBP} \beta$ can substitute for $\mathrm{C} / \mathrm{EBPa}$ in hematopoiesis and adipocyte differentiation [77, 78]. However, the mitochondrial biogenesis in fat cells is significantly altered in such mouse mutants [78]. It is conceivable that in many cases, C/EBP factors have redundant functions and act synergistically as suggested for $C / E B P \beta$ and $C / E B P \delta$ in inflammatory signaling $[79,80]$ and adipocyte differentiation [44]. Variations in expression between C/EBP members could be merely due to the divergence in the regulation of expression while preserving similar functions. For example, the inducible C/EBPS protein may support the role of $C / E B P \beta$ that exhibits a more constitutive expression pattern [81]. Furthermore, similar functions may have been channeled into different signaling pathways. For example, C/EBP $\beta$ but not $\mathrm{C} / \mathrm{EBP} \delta$ is essential for immune complex-induced lung injury in mice, whereas C/EBPS - not C/EBP $\beta$ mediates LPS-induced lung injury, although both proteins are induced by the treatments $[82,83]$. On the other hand, antagonistic roles of $\mathrm{C} / \mathrm{EBPa}$ and C/EBPS have been observed with respect to HIF-1a regulation. C/EBPa inhibits HIF-1 function by competing with HIF-1 $\alpha$ for HIF-1 $\beta$ binding [84]. In contrast, C/EBPS enhances HIF-1 activity by supporting HIF-a expression [34]. If and how these opposing functions are utilized in the same cell to modulate cell biology has not been explored. To fully understand the role of C/EBPS functions compared to other C/EBP members, more systematic functional comparisons will be necessary including in-cell analysis of heterodimers and gene replacement studies that allow for temporal and spatial control of expression.

\section{C/EBPS and the regulation of cell proliferation and differentiation}

C/EBP $\delta$ was first cloned by homology to other $\mathrm{C} / \mathrm{EBP}$ factors and was subsequently recognized as a gene that is induced during growth arrest and the differentiation of certain cell types. For example, $\mathrm{C} / \mathrm{EBP} \delta$ expression is induced during G0 growth arrest, promotes contact inhibition in mammary epithelial cells [85, 86] and fibroblasts [87], and mediates the growth arrest of mammary epithelial cell lines in response to Oncostatin M [88]. However, the effect of $\mathrm{C} / \mathrm{EBP} \delta$ on proliferation can be cell-type dependent, and may reflect its role in the expression of secreted factors and/or intracellular regulators of the cell cycle.

Ectopic C/EBPS reduces the growth rate of mammary epithelial cell lines but not of HEK293 cells [89]. These findings are in agreement with the observation that the loss of C/EBPS leads to hyperproliferation and excess branching of the mammary gland epithelium in aged mice of a mixed 129B6 strain background [90]. In cultured mammary and myeloid tumor cell lines C/EBPS promotes the downregulation of cyclin D and/or cyclin E and p27CIP2 expression $[85,89,91]$, which is consistent with the suppression of cell growth. C/EBP $\delta$ also mediates growth inhibition by IL-6 or 1,25-dihydroxyvitamin D3 in the androgen-dependent LNCaP prostate cancer cell line $[92,93]$. In contrast, another study described high basal levels of C/EBP $\delta$ expression in androgen-dependent human prostate cancer cells (three primary lines and CWR22 cells), which are further enhanced by testosterone [94]. Thus, more studies are needed to clarify if C/EBPS regulates prostate cancer cell growth or differentiation in vivo, and how its functions may be modulated by hormone-receptor signaling.

In addition to regulating the expression of intrinsic cell-cycle regulators, C/EBP $\delta$ also modulates cell proliferation and growth arrest indirectly through the expression of secreted factors. In pituitary prolactinoma cells, C/EBPS inhibits proliferation by suppressing prolactin expression [18]. On the other hand, C/EBPS promotes the proliferation of cultured osteoblasts by directly activating the expression of IGF-1 [95]. Similarly, C/EBPS promotes the proliferation of $V S M C s$ in response to IL-1 $\beta$ by inducing expression of the PDGFA-receptor [66]. These cases in which C/EBPS stimulates proliferation indirectly through secreted factors demonstrate clearly that the expression of C/EBPS does not necessarily inhibit cell proliferation and can be compatible with cell proliferation.

In addition to the regulation of proliferation, C/EBPS has also been implicated in the differentiation of certain cell types. For example, C/EBP $\delta$ expression is associated with early stages of pre-adipocyte differentiation [96, 97]. The loss of C/EBPS alone in vivo impairs the development of brown fat and further exacerbates an adipogenesis defect observed in C/EBP $\beta$ KO mice [44]. In addition, studies of adipogenic differentiation in cell culture have provided molecular evidence for a direct role of C/EBPS in tumor suppressor pathways. That is, C/EBPS (like C/EBP $\beta$ and C/EBPa) specifically associates with the hypophosphorylated form of the retinoblastoma protein, $\mathrm{Rb}$, which predominates in 
the G0/G1 phase of the cell cycle [98]. For C/EBP $\beta$ it was determined that the interaction with $\mathrm{Rb}$ potentiates promoter transactivation and promotes adipocyte differentiation; this interaction must be regulated by additional factors or specific modifications, because it is only seen in differentiating cells [98]. On the other hand, $\mathrm{Rb}$ interferes with reporter gene transactivation by C/EBPS in the HeLa and A431 cancer cell lines where C/EBPS attenuates the activity of the $\mathrm{Rb}$ partner E2F-1 and promotes apoptosis [99]. In breast cancer cell lines, C/EBPS promotes phosphorylation of $\mathrm{Rb}$, which is associated with $\mathrm{Rb}^{\prime} \mathrm{s}$ tumor suppressor function, through downregulation of the kinase inhibitor cyclin D1 [56]. In a BCR-ABL-positive cell line (KCL22), C/EBPS also interacts with Rb and E2F-1 and induces growth arrest and myeloid differentiation [91]. In summary, while the reported details vary, C/EBPS's intersection with the Rb pathway has been correlated with cell death, differentiation, and inhibition of oncogenic transformation.

Consistent with these observations, a number of reports point to a tumor-suppressor function of C/EBPS in the myeloid lineage. The CEBPD promoter is silenced in $35 \%$ of 260 human acute myeloid leukemia samples [8], and its expression is downregulated in the blast crisis phases of chronic myelogenous leukemia (CML) [100]. The overexpression of C/EBPס in primary mouse hematopoietic progenitor cells or a cell line model of acute myelogenous leukemia (AML) leads to myeloid differentiation accompanied by upregulation of the G-CSF receptor and downregulation of c-myc expression $[8,101]$, as also seen in CML cell lines [91]. Indeed, C/EBPS is expressed in differentiated granulocytes/neutrophils [91, 102]. In macrophages, C/EBPS regulates many genes associated with functions of differentiated cells [21] and is specifically associated with M1 macrophage polarization [55]. While direct experimental evidence from mouse models is still missing, the potential tumor suppressor function of C/EBPS in AML and possibly CML is most likely due to its function in stimulating differentiation, which may or may not be correlated with its function in cell cycle arrest.

The antithesis of the differentiated cell is the undifferentiated stem cell, with its self-renewal capacity. Very little information exists about C/EBPS expression or functions in stem cells. One report describes C/EBPS expression in limbal stem cells of the eye, where it maintains p63 expression, prolongs the cell cycle, and maintains stemness [103]. In addition, C/EBPS expression was observed in cultured long-term self-renewing neural stem cells, dependent on the stem-cell maintenance factor LIF [104]. A role for C/EBPS in stem-cell maintenance is consistent with its ability to downregulate drivers of the cell cycle. Interestingly, FBXW7a, which inhibits and is inhibited by C/EBPS [34, 57], has been implicated in promoting stem-cell differentiation, pluripotency, and quiescence, depending on the cell type [105-107]. Therefore, the potential roles and mechanisms of C/EBPS signaling in stem/progenitor cells are a promising but currently under-explored area of research.

\section{C/EBPD and the regulation of cell death and survival}

The first evidence for C/EBPS's ability to promote cell death came from the observation that ectopic C/EBPS exacerbates the death of growth factor-deprived mammary epithelial cells [85]. C/EBPS also promotes the cell death required for lumen formation when transformed mammary epithelial cells are cultured as 3D acini on matrigel [56]. Indeed, the loss of C/EBP delays cell death at the onset of the mammary gland involution that follows lactation [70]. Furthermore, in the context of this physiological cell death, C/EBP $\delta$ is induced by STAT3 and is necessary for the downregulation of cyclin D1, upregulation of p53 and IGFBP5, and proper regulation of several members of the Bcl family [70]. C/EBPS's ability to promote cell death in mammary epithelial cells suggests that it has potential as a tumor suppressor for breast cancer. In support of this notion, C/EBPS expression is downregulated with breast cancer progression [108], and the loss of C/EBPS increases tumor multiplicity in the MMTV-Neu mammary tumor model [34].

Interestingly, the transcription factor STAT3, which promotes cell death during mammary gland involution [109] is, on the other hand, frequently activated in breast cancer [110], and promotes metastasis in the MMTV-Neu mouse model, along with expression of Cebpd and an inflammatory and proangiogenic signature [111]. Indeed, despite the increased number of tumors in Cebpd KO mice, the loss of Cebpd results in a significantly reduced incidence of lung metastasis, which correlates with C/EBPS's role in supporting HIF-1a expression and the consequent cell survival under hypoxia [34]. In addition, C/EBPS can promote cell survival in response to DNA-damaging agents (see next section for more detail). Given that growth arrest is necessary for DNA repair and adaptation to hypoxia, it is conceivable that the growth arrest functions of C/EBPS contribute to its promotion of survival under stress conditions.

In another example of $\mathrm{C} / \mathrm{EBP}^{\prime} \mathrm{s}$ role in cell death, the $\beta$-diketone anti-cancer drug HMDB induces its expression, and C/EBP $\delta$ augments cervical tumor cell death and the activation of PPARG2 and 
GADD153/CHOP (CHOP) transcription in response to HMDB [99]. On the other hand, C/EBPS protects pancreatic $\beta$ cells from cytokine-induced cell death by attenuating the expressions of GADD153/CHOP and STAT1 [112]. These are examples of the cell type- and context-dependent functions of $\mathrm{C} / \mathrm{EBP} \delta$, as the same target gene(s) may be associated with opposite outcomes in different cell types.

Collectively, these reports indicate that C/EBPS by itself is not a cell death inducer. Rather, C/EBPS can promote cell death or survival, perhaps as a cell type- and context-dependent interpreter of extracellular signals.

\section{C/EBPठ and genome integrity}

Several reports indicate a role for C/EBPS in the DNA damage response and genomic integrity. C/EBPS renders urothelial bladder carcinoma cell lines resistant to cisplatin, due to its role in expression of the $\mathrm{Cu} / \mathrm{Zn}$-superoxide dismutase SOD1, which scavenges reactive oxygen species [113]. The loss of C/EBPS results in centrosome amplification and genomic instability in cultured mouse embryo fibroblasts (129S1 strain) [87]. This may be due in part to C/EBPS's role in promoting the degradation of cyclin D1 [89] and in the Fanconi Anemia (FA) replication-associated DNA repair pathway. C/EBPS promotes the nuclear import of FANCD2, a critical protein for the FA pathway, by physically interacting with FANCD2 and the importin IPO4. This so-far unique non-transcriptional function of C/EBPS may underlie its role in promoting cell survival in response to the DNA-damaging agent mitomycin C [41]. However, the loss of C/EBPS is not sufficient to cause tumors in mice. Hence, the role of C/EBPS in genomic stability may be compensated for in vivo and/or is only critical when cells are challenged by stress conditions such as in vitro or microenvironmental stressors, drugs, or mutations. On the other hand, C/EBPS can also contribute to genomic instability by directly inducing the expression of Aurora $C$ kinase, which leads to centrosome abnormalities in cervical carcinoma cells that have been treated with TNFa [114]. This last study highlights how C/EBPס may switch functions specifically under inflammatory conditions.

\section{Role of C/EBP $\delta$ in inflammatory responses}

One of the earliest discoveries about C/EBP $\delta$ was that its expression is induced by LPS from gram-negative bacteria and by pro-inflammatory cytokines in many cell types and tissues [1]. Studies of $\mathrm{C} / \mathrm{EBP \delta}$ in inflammatory signaling have focused on cells of the myeloid lineage [1]. Collectively, the re- ports suggest a role for C/EBPS in the activation of the innate immune response and in the generation of pro-inflammatory conditions. However, a few reports also point to possible functions of C/EBPS in the inhibition of inflammation. In addition, other C/EBP family members play critical roles in the innate immune response and inflammation (e.g.[115,116,5]), and it remains to be determined how mutual regulation or distinct functions are played out in the overall control of the inflammatory response.

C/EBPS amplifies LPS signaling in macrophages, supports the expression of many LPS-induced genes, and is necessary to clear persistent gram-negative bacterial infections [21]. Innate immune responses are largely mediated by toll-like receptors (TLRs), which act as a primary line of defense against pathogens, and activate the NFKB and IRF3 transcription program [117]. Mechanistically, C/EBPS promotes LPS responses in part by inducing the expression of the LPS-receptor TLR4 and by inhibiting FBXW7 expression. In turn, FBXW7a downregulates $\mathrm{C} / \mathrm{EBP \delta}$ expression and is an attenuator of inflammatory signaling $[34,57]$. This negative feedback loop reveals an important role of the C/EBP $/$ FBXW7 $\alpha$ pathway in inflammatory signaling and opens up new avenues for investigation of their functions in immune cells and inflammation-associated diseases.

C/EBPS also binds directly and activates the promoters of many LPS-induced genes [21]. However, because C/EBP $\delta$ also induces expression of the LPS receptor subunit TLR4 [57], some of the reported defects in LPS responses due to Cebpd-null mutations or siRNA could also be due to reduced levels of the LPS receptor itself. For example, TLR4 reconstitution partially rescues the LPS-induced IL-6 expression in Cebpd null cells [57]. Interestingly, a low dose of LPS specifically induces $\mathrm{C} / \mathrm{EBP} \delta$ expression rather than NFKB [118], and the suppressor of cytokine signaling 3 (SOCS3) attenuates LPS-induced activation of C/EBPS but not of NFKB [119]. Together, these findings suggest that $\mathrm{C} / \mathrm{EBP} \delta$ is critical in sensitizing cells to LPS and prepares them for activation of the innate immune response. Accordingly, C/EBPS is necessary for lung infiltration by macrophages and to clear pulmonary infection by Klebsiella pneumoniae [75]. On the other hand, the loss of C/EBPS protects against infection by $S$. pneumoniae [120]. While this result appears at odds with the aforementioned reports, this particular phenotype is explained by the role of $\mathrm{C} / \mathrm{EBP \delta}$ in lung epithelial expression of PAFR, the receptor used by S. pneumoniae to enter the organism [120]. Therefore, the relative resistance of Cebpd-null mutant mice to $S$. pneumoniae is unrelated to C/EBPS's role in the immune system. 
Although inflammatory responses are essential for activation of the innate immune response and to enhance adaptive immunity, excessive inflammation is detrimental and can lead to autoimmune disorders and cancer (or sepsis in the case of bacterial triggers) [121]. Indeed, a Cebpd null mutation partly protects mice from sepsis, i.e. disseminated intravascular coagulation (DIC)-induced mortality in response to LPS [122]. Furthermore, C/EBPS deficiency protects against LPS-induced lung injury [82]. In contrast, $\mathrm{C} / \mathrm{EBP} \delta$ deficiency does not protect against immune-complex-induced lung injury [83], although it participates in $\mathrm{Fcy}$ receptor-mediated activation of cultured macrophages [79]. These data indicate that the role of C/EBPS in inflammation depends in part on the inflammatory stimulant. Because most studies so far have used LPS, C/EBPS's role in the response to other specific triggers of the innate immune response still needs to be determined. Interestingly, a Cebpd null mutation has profound effects on the expression of several TLR genes in peritoneal macrophages [57], raising the possibility that $\mathrm{C} / \mathrm{EBP} \delta$ has a much broader role in the innate immune response beyond LPS.

So-called sterile inflammation in the absence of foreign antigens also contributes to pathological conditions. CEBPD expression is induced by inflammatory cytokines, including IL-6, and in turn C/EBPS directly activates IL-6 gene expression [123], providing the potential for an autocrine pro-inflammatory feedback loop. C/EBPS expression in astrocytes is implicated in the pathology of Alzheimer disease through the activation of inflammatory cytokines and pentraxin-3 (PTX3), a secreted molecule shown to inhibit the phagocytosis of damaged neurons by macrophages [124, 125]. In CNS dendritic cells, C/EBPS suppresses the expression of IL-10, consequently altering the ratio of $\mathrm{T}$ helper17 cells $\left(\mathrm{Th}_{17}\right)$ and $\mathrm{T}$ regulatory cells $\left(\mathrm{T}_{\mathrm{reg}}\right)$, and thereby contributing to the severity of experimental autoimmune encephalomyelitis [126]. C/EBPS is also implicated in the promotion of amyotrophic lateral sclerosis, because of its expression in the activated microglia of patients and in a mouse model of this disease, and because it promotes the expression of inflammatory cytokines in the brain in response to systemic LPS [127]. Indeed, the anti-inflammatory flavanoid chrysin inhibits microglial C/EBPS expression and the concomitant neural cell death in culture [128].

In another inflammatory pathology, C/EBPS promotes the pathogenesis of collagen-induced rheumatoid arthritis in mice, most likely by contributing to the expression of chemokines and cytokines in macrophages that promote the formation of endothelial cell tubes and the migration and proliferation of synoviocytes [129]. In addition, C/EBPS mediates the IL-1 $\beta$-induced expression of secreted type IIA phospholipase $\mathrm{A}(2)$ in chondrocytes, which can also contribute to rheumatoid arthritis [130]. Taken together, these reports strongly support a role for $\mathrm{C} / \mathrm{EBP} \delta$ in the pathology of chronic inflammation and autoimmune disorders.

A few reports point to additional anti-inflammatory functions for C/EBP $\delta$. For example, $\mathrm{C} / \mathrm{EBP \delta}$ expression can be induced by glucocorticoids and $\mathrm{PGE}_{2}$, which are potent anti-inflammatory and immunosuppressant agents [54, 131, 132]. Most strikingly, C/EBPS attenuates the Il-1 $\beta+$ IFN- $\gamma$-induced chemokine production in rat insulinoma cells by promoting the expression of IRF-1 [112]. The role of C/EBPS in supporting or inhibiting inflammatory signaling may depend on the context or cell type. Indeed, C/EBPS activates the expression of anti-inflammatory IL-10 in response to LPS or $\mathrm{PGE}_{2}$ in macrophages [54, 133]. On the other hand, a Cebpd null mutation leads to increased IL-10 expression in dendritic cells, which is associated with the progression of CNS autoimmune inflammatory disease [126]. Elevated IL-10 mRNA levels have also been observed in Cebpd null mammary tumor tissue [57]; however, it remains to be determined if this is due to a direct or indirect role of C/EBPS.

Negative feedback regulation of C/EBPS expression appears to play an important role in the resolution of inflammation and can be achieved through ATF-3 [21], Myc, and the Myc-interacting protein Miz1 [134, 135]. It will be very interesting to learn if and how C/EBPS, ATF3, and the Myc/Miz1 complex engage in mutual regulatory feedback loops to modulate the magnitude and duration of inflammatory signaling.

Interestingly, C/EBPS can activate an indirect negative feedback mechanism by inducing the expression of the peroxisome proliferator-activated receptor-gamma (PPAR $\gamma$ ), a member of the nuclear receptor superfamily, in VSMCs. PPAR $\gamma$ plays a key role in the inhibition of inflammation, in part by inactivating the STAT3 transcription factor, thereby downregulating $C E B P D$ expression [136]. PPARy agonists are currently in clinical trials for the treatment of many inflammatory disorders [137]. Thus, by inducing PPARy expression, C/EBPS contributes to the attenuation of inflammatory responses in the early stages of atherosclerosis [136]. On the other hand, sumoylated C/EBPS is reported to inhibit PPARY gene transcription in hepatocytes [36]. Therefore, the regulation of C/EBPS's sumoylation may provide a mechanism for increasing the inflammatory response. The potential for another feedback loop was raised in a report on the role of IKKi/IKK (IKBKE) in the LPS induction of 
C/EBPS expression and activity, in which C/EBPS was found to bind to the IKBKE promoter [61]. However, it is not known if IKBKE expression is reduced or activated by C/EBPS.

As mentioned earlier, C/EBP $\delta$ also inhibits its own suppressor. C/EBPS protein is targeted for ubiquitination and degradation by FBXW7a, and $F B X W 7 a$ gene expression is in turn inhibited by $\mathrm{C} / \mathrm{EBP} \delta$. This negative feedback loop depends on GSK-3 $\beta^{\prime}$ s phosphorylation of C/EBPS, which is inhibited by LPS. Therefore, LPS leads to the stabilization of C/EBPS [57]. Interestingly, GSK3 $\beta$ is mostly known as a driver of inflammation, and its inhibitors are under investigation as therapeutics for a variety of diseases [138]. The discovery that GSK-3 $\beta$ can promote the degradation of $\mathrm{C} / \mathrm{EBP} \delta$ therefore opens up new avenues for investigation into the cross-talk between signaling pathways and the regulation of the innate immune response and inflammation.

\section{C/EBPS expression in human cancers}

In accordance with the diversity of C/EBPS functions described above, analyses of C/EBPS expression in human cancers paint a similarly complex picture, indicating that it functions both as a tumor suppressor and tumor promoter. In breast cancer, CEBPD mRNA is downregulated with malignant progression, i.e. it is significantly reduced or undetectable in invasive/metastatic disease $[108,139,140]$, and $C E B P D$ is part of a 70-gene signature that correlates with longer survival of breast cancer patients [141]. These data suggest that C/EBPS has a tumor-suppressor function. On the other hand, C/EBPS protein expression is positively correlated with cyclin $\mathrm{D} 1$ and cyclin $\mathrm{E}$ in human breast cancer tissue [72], in contrast to several reports showing that C/EBPS downregulates these cyclins in cultured cell models $[85,89,91,93]$. While this study [72] did not analyze the correlation of C/EBPS expression with survival/prognosis, proliferation markers are usually correlated with poor prognosis. Thus, it will be very interesting to follow up on this initial report with a more extensive analysis of C/EBPS protein expression in breast cancer, especially given that findings from a mouse model suggest that C/EBP $\delta$ has a dual activity as tumor suppressor and a promoter of metastasis [34].

In support of a tumor suppressor function, C/EBPS protein expression correlates with longer disease-free survival in meningioma patients [73]. $C E B P D$ gene methylation was identified in breast, liver, and cervical carcinomas [142, 143]. A recent report suggests that metastatic lesions in breast cancer patients exhibit a higher incidence of methylation within a CPG island of $C E B P D$, which was associated with increased risk of relapse [144]. Consistent with the observation that C/EBPS promotes myeloid differentiation in cell culture models (see above), the $C E B P D$ promoter was found to be silenced in $35 \%$ of 260 human acute myeloid leukemia cases [8] and its expression is downregulated in the blast crisis phases of CML [100]. Interestingly, in the U937 leukemia cell line, eicosapentaenoic acid causes the demethylation of a specific $C p G$ in the $C E B P D$ promoter, increased C/EBPS expression, and cell differentiation [145]. Furthermore, the CEBPD gene resides within a common fragile site that is frequently lost in certain cancer cell lines. However, it is not known if this finding has any functional bearing on the behavior of tumor cells or is a byproduct of CEBPD's vicinity to the KIAA0146 gene [146]. While these data are consistent with a tumor-suppressor function of $\mathrm{C} / \mathrm{EBPS}$, mutations in $C E B P D$ are not common in breast cancer [147]. In addition, analyses of the CEBPD gene sequence in leukemias, lymphomas, and a variety of solid tumors indicate that mutations of CEBPD may not contribute to the development of neoplastic disease [148]. Interestingly, single nucleotide polymorphisms in the CEBPD gene are infrequent, perhaps indicative of a stringent need for gene conservation, and none has so far been associated with disease(s) $[149,150]$

As in breast cancer, CEBPD mRNA is downregulated in human and rat prolactinomas, and C/EBPS inhibits prolactinoma cell proliferation in culture through the inhibition of prolactin expression [18, 151]. In contrast, CEBPD mRNA levels are upregulated in mesothelioma [152], gliomas [7], and in Anaplastic Large Cell Lymphoma but not in Hodgkin's Lymphoma [153]. However, correlation studies of expression and cancer biology will be more informative if performed at the protein level, because the C/EBPS level can be regulated by its protein stability $[56,57]$, and the CEBPD mRNA expression level may not therefore correlate with the protein level and hence function. Furthermore, analysis in the context of tissue histology will be necessary in light of $\mathrm{C} / \mathrm{EBP \delta}$ 's potential expression in tumor-infiltrating host cells.

A strong case for $\mathrm{C} / \mathrm{EBP} \delta$ as a tumor promoter can be made in brain cancer. CEBPD mRNA is overexpressed in mesenchymal glioblastoma cells and associated with poor prognosis $[7,154]$. C/EBPS protein expression is detected near necrotic glioblastoma tissue [7]. Based on the observation that C/EBPS promotes HIF-1a expression and survival under hypoxic conditions [34], we speculate that this function is responsible for the association of C/EBPS expression with poor prognosis in glioblastoma (see also section below). Furthermore, C/EBPS inhibits the 
expression of FBXW7a in glioblastoma cell lines [34]. FBXW7a is a substrate-binding subunit of the SCF E3 ubiquitin ligase complex and targets many oncoproteins for degradation, including mTOR, NOTCH, c-myc, and cyclin E [59] and is a bona fide tumor suppressor in glioblastoma [155]. Therefore, we suggest that C/EBPS's inhibition of FBXW7a contributes to glioblastoma progression.

Taken together, expression studies in human neoplasias suggest that C/EBPS can be associated with and contribute to either a better or worse prognosis, depending on the tumor type or cell of origin. Given the role of C/EBPS in inflammation and the cross-talk between tumor cells and the immune system, care must be taken to determine if the expression of C/EBPS is associated with a cell differentiation state, hypoxic or inflammatory induction, or is a result of immune cell infiltration.

\section{Role of C/EBPס in cancer: a special case for hypoxia and inflammation?}

Accumulating evidence supports a role for hypoxia and inflammation in the progression of tumors $[156,157]$. As outlined above, C/EBPS expression is induced by inflammatory effectors and hypoxia, and it promotes pro-inflammatory signaling and adaptation to hypoxia. Thus, C/EBPS expression and functions are strongly associated with conditions that correlate with cancer progression, which is in contrast to its initial designation as a tumor suppressor. Mechanistically, one C/EBPS pathway stands out as highly relevant for both conditions. Inhibition of the tumor suppressor FBXW7a by C/EBPS leads to the upregulation of many oncoproteins and indirectly to the upregulation of HIF-1a [34, 57], which has a prominent role in hypoxia adaptation, inflammation, and cancer [59, 158]. Consistent with this notion, MMTV-Neu-induced mammary tumors arising in Cebpd null mice are less metastatic than those arising in control mice [34], and the growth of experimental metastases of a lung cancer cell line is impaired in Cebpd null host mice [48]. Furthermore, C/EBPS is associated with a mesenchymal phenotype and poor prognosis in glioblastoma $[7,154]$.

The association of C/EBPS with hypoxia and inflammation raises additional questions. For example, although HIF-1a has many pro-oncogenic functions, it too can act as a tumor suppressor or promote therapeutic responses [159]. Indeed, HIF-1a can promote cell survival or cell death depending on the degree of hypoxia [160]. However, it is unclear if C/EBPS supports HIF-1a expression and function under all of these conditions. Furthermore, it remains to be determined how HIF-1-independent functions of
C/EBPS affect cells under hypoxic conditions and whether HIF-1 induces CEBPD expression directly.

Monocyte and dendritic cell infiltrations are seen in the hypoxic regions of solid tumors, particularly associated with necrotic tissue, and HIF- $1 \alpha$ is required for the recruitment of myeloid cells [161]. Does C/EBPS support the recruitment of monocytes to the tumors and/or the function of tumor-associated macrophages (TAMs)? Altered cytokine/chemokine expression patterns in Cebpd null mammary tumors suggest that the answer is yes [57]. The immune system's role is to eliminate tumor cells, and subversion of the immune system by the tumor leads to escape from immune surveillance and the promotion of chronic inflammatory signaling. Interestingly, C/EBPS promotes the differentiation of bone-marrow macrophages to the classical M1 type, while Cebpd silencing promotes the alternatively activated M2-type, which is considered immunosuppressive [55]. This finding suggests a potential tumor-suppressor function of C/EBPS in the immune system. Indeed, it is conceivable that C/EBPS functions in the innate immune response may contribute to the reduced tumor burden of Cebpd null mice in the mammary tumor model [34]. On the other hand, a very recent study indicates that $\mathrm{C} / \mathrm{EBP} \delta$ expression in TAMs correlates by several measures with the malignant progression of nasopharyngeal carcinoma [54]. Thus, an important question to resolve is the role of C/EBPS in tumor cells as opposed to in the tumor microenvironment along tumor progression. It needs to be determined what types of immune cells express C/EBPS in vivo and how C/EBPS's functions in these cells affect the metastatic phenotype. The dual role of C/EBPS is reminiscent of the "TGF- $\beta$ paradox" [11, 12]. While TGF- $\beta$ has been shown to inhibit C/EBPס expression and activity in VSMCs and pre-adipocytes respectively $[40,162]$ an interesting open question is the extent of cross-talk between TGF- $\beta$ and C/EBP $\delta$ signaling in tumor and immune cells. A conditional null allele of C/EBP $\delta$, which is being developed in our laboratory, will be useful for addressing some of the above questions in mouse models.

\section{Summary and Perspectives}

In this review we have highlighted the versatile nature of the C/EBPS protein, a transcription factor that can activate or repress target genes and promotes many different, and sometimes contrasting, cellular functions, depending on context, that can affect intracellular functions and/or the microenvironment. C/EBPS even exhibits at least one documented non-transcriptional function. We propose that C/EBP $\delta$ has potential as a tumor suppressor when it inhibits proliferation, promotes differentiation, con- 
tributes to genomic integrity, and supports the innate immune response. On the other hand, C/EBP $\delta$ promotes tumor progression through its functions in hypoxia adaptation and pro-inflammatory signaling, which may also operate in the tumor parenchyma and the tumor microenvironment (Figure 2).

Far too little is known about physiologically relevant $\mathrm{C} / \mathrm{EBP} \delta$ protein modifications or how spe- cific protein interactions are regulated and affect the regulation of $\mathrm{C} / \mathrm{EBP} \delta$ target genes and $\mathrm{C} / \mathrm{EBP} \delta$ 's cell-type-specific activities. Because C/EBP $\delta$ is linked to so many cellular functions, insights into its roles and regulation will lead to a better understanding of the complexity and diversity of cellular processes in the normal development and progression of diseases.

\section{C/EBPS}

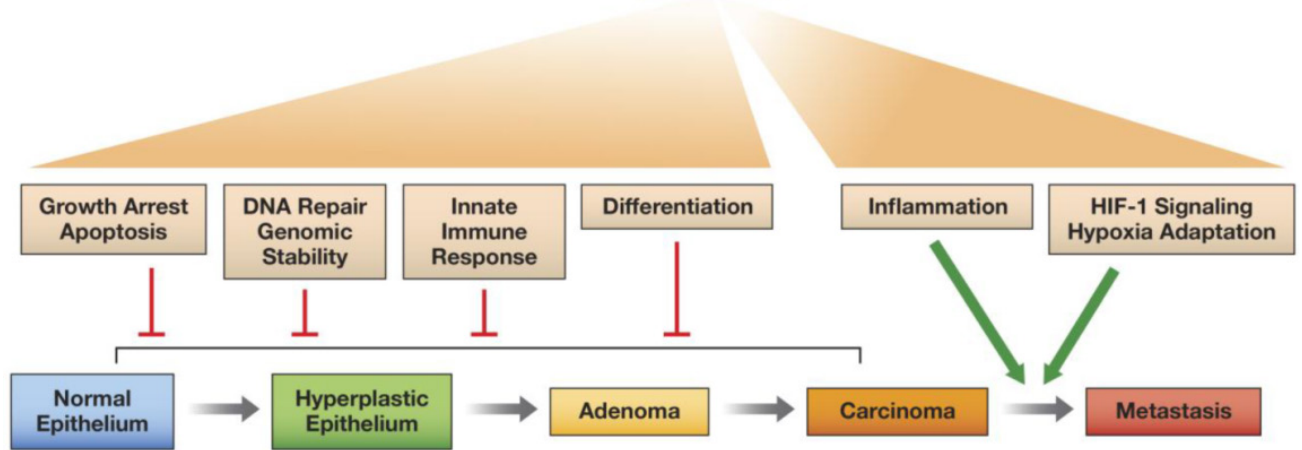

Fig 2. Model for the differential effects of C/EBPD on epithelial tumor progression. C/EBP $\delta$ may function as a tumor suppressor at the early stages of tumor development, because of its role in promoting growth arrest, cell death, differentiation, DNA repair, genomic stability, and the innate immune response. However, by supporting HIF-I activity and hypoxia adaptation and by amplifying inflammatory signaling, C/EBPठ promotes tumor progression.

\section{Acknowledgements}

The authors are supported by the Intramural Research Program of the NIH, National Cancer Institute. We are grateful to Drs. Peter Johnson, Howard Young, and Ju-Ming Wang for helpful discussion and critical comments on the manuscript, and Allen Kane for preparation of the figures. We apologize for not citing all the publications in the field and welcome feedback.

The content of this publication does not necessarily reflect the views of policies of the Department of Health and Human Services, nor does the mention of trade names, commercial products, or organizations imply endorsement by the U.S. Government.

\section{Competing Interests}

The authors have declared that no conflict of interest exists.

\section{References}

1. Ramji DP, Foka P. CCAAT/enhancer-binding proteins: structure, function and regulation. Biochem J. 2002; 365: 561-75. doi:10.1042/BJ20020508.

2. Tsukada J, Yoshida Y, Kominato Y, Auron PE. The CCAAT/enhancer (C/EBP) family of basic-leucine zipper (bZIP) transcription factors is a multifaceted highly-regulated system for gene regulation. Cytokine. 2011; 54: 6-19. doi:10.1016/j.cyto.2010.12.019.

3. Nerlov C. The C/EBP family of transcription factors: a paradigm for interaction between gene expression and proliferation control. Trends Cell Biol. 2007; 17: 318-24. doi:10.1016/j.tcb.2007.07.004.

4. Sebastian T, Johnson PF. Stop and go: anti-proliferative and mitogenic functions of the transcription factor C/EBPbeta. Cell Cycle. 2006; 5: 953-7.

5. Roos $\mathrm{AB}$, Nord $\mathrm{M}$. The emerging role of $\mathrm{C} / \mathrm{EBPs}$ in glucocorticoid signaling: lessons from the lung. J Endocrinol. 2012; 212: 291-305. doi:10.1530/JOE-11-0369.
6. Takiguchi M. The C/EBP family of transcription factors in the liver and other organs. Int J Exp Pathol. 1998; 79: 369-91.

7. Cooper LA, Gutman DA, Chisolm C, Appin C, Kong J, Rong Y, et al. The tumor microenvironment strongly impacts master transcriptional regulators and gene expression class of glioblastoma. The American journal of pathology. 2012; 180: 2108-19. doi:10.1016/j.ajpath.2012.01.040.

8. Agrawal S, Hofmann WK, Tidow N, Ehrich M, van den Boom D, Koschmieder $\mathrm{S}$, et al. The C/EBPdelta tumor suppressor is silenced by hypermethylation in acute myeloid leukemia. Blood. 2007; 109: 3895-905. doi:10.1182/blood-2006-08-040147.

9. Hanahan D, Weinberg RA. Hallmarks of cancer: the next generation. Cell. 2011; 144: 646-74. doi:10.1016/j.cell.2011.02.013.

10. Egeblad M, Nakasone ES, Werb Z. Tumors as organs: complex tissues that interface with the entire organism. Dev Cell. 2010; 18: 884-901. doi:10.1016/j.devcel.2010.05.012.

11. Tian M, Schiemann WP. The TGF-beta paradox in human cancer: an update. Future Oncol. 2009; 5: 259-71. doi:10.2217/14796694.5.2.259.

12. Roberts $\mathrm{AB}$, Wakefield $\mathrm{LM}$. The two faces of transforming growth factor beta in carcinogenesis. Proc Natl Acad Sci U S A. 2003; 100: 8621-3. doi:10.1073/pnas.1633291100.

13. Grigoryan G, Reinke AW, Keating AE. Design of protein-interaction specificity gives selective bZIP-binding peptides. Nature. 2009; 458: 859-64. doi:10.1038/nature07885.

14. Rouschop KM, van den Beucken T, Dubois L, Niessen H, Bussink J, Savelkouls $\mathrm{K}$, et al. The unfolded protein response protects human tumor cells during hypoxia through regulation of the autophagy genes MAP1LC3B and ATG5. The Journal of clinical investigation. 2010; 120: 127-41. doi:10.1172/JCI40027.

15. Osada $\mathrm{S}$, Yamamoto $\mathrm{H}$, Nishihara $\mathrm{T}$, Imagawa $\mathrm{M}$. DNA binding specificity of the CCAAT/enhancer-binding protein transcription factor family. J Biol Chem. 1996; 271: 3891-6.

16. Zhou J, Gurates B, Yang S, Sebastian S, Bulun SE. Malignant breast epithelial cells stimulate aromatase expression via promoter II in human adipose fibroblasts: an epithelial-stromal interaction in breast tumors mediated by CCAAT/enhancer binding protein beta. Cancer Res. 2001; 61: 2328-34.

17. Enwright JF, 3rd, Kawecki-Crook MA, Voss TC, Schaufele F, Day RN. A PIT-1 homeodomain mutant blocks the intranuclear recruitment of the CCAAT/enhancer binding protein alpha required for prolactin gene transcription. Mol Endocrinol. 2003; 17: 209-22.

18. Tong Y, Zhou J, Mizutani J, Fukuoka H, Ren SG, Gutierrez-Hartmann A, et al. CEBPD suppresses prolactin expression and prolactinoma cell proliferation. Molecular endocrinology. 2011; 25: 1880-91. doi:10.1210/me.2011-1075.

19. Zhang $Y$, Liu T, Yan P, Huang T, Dewille J. Identification and characterization of CCAAT/enhancer binding protein delta (C/EBPdelta) target genes in G0 growth arrested mammary epithelial cells. BMC Mol Biol. 2008; 9: 83. doi:10.1186/1471-2199-9-83.

20. Borrelli S, Fanoni D, Dolfini D, Alotto D, Ravo M, Grober OM, et al. C/EBPdelta Gene Targets in Human Keratinocytes. PLoS One. 2010; 5: e13789. doi:10.1371/journal.pone.0013789. 
21. Litvak V, Ramsey SA, Rust AG, Zak DE, Kennedy KA, Lampano AE, et al. Function of C/EBPdelta in a regulatory circuit that discriminates between transient and persistent TLR4-induced signals. Nat Immunol. 2009; 10: 437-43. doi:10.1038/ni.1721.

22. Kovacs KA, Steinmann M, Magistretti PJ, Halfon O, Cardinaux JR. CCAAT/enhancer-binding protein family members recruit the coactivator CREB-binding protein and trigger its phosphorylation. J Biol Chem. 2003; 278: 36959-65. doi:10.1074/jbc.M303147200.

23. Wang JM, Ko CY, Chen LC, Wang WL, Chang WC. Functional role of NF-IL6beta and its sumoylation and acetylation modifications in promoter activation of cyclooxygenase 2 gene. Nucleic Acids Res. 2006; 34: 217-31. doi:10.1093/nar/gkj422.

24. Chamberlain W, Gonnella P, Alamdari N, Aversa Z, Hasselgren PO. Multiple muscle wasting-related transcription factors are acetylated in dexamethasone-treated muscle cells. Biochemistry and cell biology = Biochimie et biologie cellulaire. 2012; 90: 200-8. doi:10.1139/o11-082

25. Chiang BT, Liu YW, Chen BK, Wang JM, Chang WC. Direct interaction of C/EBPdelta and Sp1 at the GC-enriched promoter region synergizes the IL-10 gene transcription in mouse macrophage. J Biomed Sci. 2006; 13: 621-35. doi:10.1007/s11373-006-9101-y.

26. Meruvu S, Hugendubler L, Mueller E. Regulation of adipocyte differentiation by the zinc finger protein ZNF638. The Journal of biological chemistry. 2011; 286: 26516-23. doi:10.1074/jbc.M110.212506.

27. Zhang J, Chang L, Chen C, Zhang M, Luo Y, Hamblin M, et al. Rad GTPase inhibits cardiac fibrosis through connective tissue growth factor. Cardiovasc Res. 2011; 91: 90-8. doi:10.1093/cvr/cvr068.

28. Bezy O, Elabd C, Cochet O, Petersen RK, Kristiansen K, Dani C, et al. Delta-interacting protein A, a new inhibitory partner of CCAAT/enhancer-binding protein beta, implicated in adipocyte differentiation. J Biol Chem. 2005; 280: 11432-8. doi:10.1074/jbc.M411741200.

29. Delany AM, Durant D, Canalis E. Glucocorticoid suppression of IGF I transcription in osteoblasts. Mol Endocrinol. 2001; 15: 1781-9.

30. Okazaki K, Li J, Yu H, Fukui N, Sandell LJ. CCAAT/enhancer-binding proteins beta and delta mediate the repression of gene transcription of cartilage-derived retinoic acid-sensitive protein induced by interleukin-1 beta. J Biol Chem. 2002; 277: 31526-33. doi:10.1074/jbc.M202815200. M202815200 [pii].

31. Lacorte JM, Beigneux A, Parant M, Chambaz J. Repression of apoC-III gene expression by TNFalpha involves C/EBPdelta/NF-IL6beta via an IL-1 independent pathway. FEBS Lett. 1997; 415: 217-20.

32. Lacorte JM, Ktistaki E, Beigneux A, Zannis VI, Chambaz J, Talianidis I Activation of CAAT enhancer-binding protein delta (C/EBPdelta) by interleukin-1 negatively influences apolipoprotein C-III expression. J Biol Chem. 1997; 272: 23578-84

33. Qiu X, Aiken KJ, Chokas AL, Beachy DE, Nick HS. Distinct functions of CCAAT enhancer-binding protein isoforms in the regulation of manganese superoxide dismutase during interleukin-1beta stimulation. J Biol Chem. 2008; 283: 25774-85. doi:10.1074/jbc.M801178200.

34. Balamurugan K, Wang JM, Tsai HH, Sharan S, Anver M, Leighty R, et al. The tumour suppressor C/EBPdelta inhibits FBXW7 expression and promotes mammary tumour metastasis. EMBO J. 2010; 29: 4106-17. doi:emboj2010280 [pii] 10.1038/emboj.2010.280.

35. Turgeon N, Valiquette C, Blais M, Routhier S, Seidman EG, Asselin C. Regulation of C/EBPdelta-dependent transactivation by histone deacetylases in intestinal epithelial cells. J Cell Biochem. 2008; 103: 1573-83. doi:10.1002/jcb.21544

36. Lai PH, Wang WL, Ko CY, Lee YC, Yang WM, Shen TW, et al. HDAC1/HDAC3 modulates PPARG2 transcription through the sumoylated CEBPD in hepatic lipogenesis. Biochim Biophys Acta. 2008; 1783: 1803-14. doi:S0167-4889(08)00225-5 [pii] 10.1016/j.bbamcr.2008.06.008.

37. Xu L, Panel V, Ma X, Du C, Hugendubler L, Gavrilova O, et al. The winged helix transcription factor foxa3 regulates adipocyte differentiation and depot-selective fat tissue expansion. Mol Cell Biol. 2013; 33: 3392-9. doi:10.1128/MCB.00244-13.

38. Turgeon N, Rousseau D, Roy E, Asselin C. GATA-4 modulates C/EBP-dependent transcriptional activation of acute phase protein genes. Biochem Biophys Res Commun. 2008; 370: 371-5. doi:S0006-291X(08)00603-7 [pii] 10.1016/j.bbrc.2008.03.107.

39. McCarthy TL, Ji CH, Chen Y, Kim KK, Imagawa M, Ito Y, et al. Runt domain factor (Runx)-dependent effects on CCAAT/enhancer-binding protein delta expression and activity in osteoblasts. Journal of Biological Chemistry. 2000; 275: 21746-53. doi:Doi 10.1074/Jbc.M002291200.

40. Choy L, Derynck R. Transforming growth factor-beta inhibits adipocyte differentiation by Smad3 interacting with CCAAT/enhancer-binding protein (C/EBP) and repressing C/EBP transactivation function. J Biol Chem. 2003; 278: 9609-19. doi:10.1074/jbc.M212259200.

41. Wang J, Sarkar TR, Zhou M, Sharan S, Ritt DA, Veenstra TD, et al. CCAAT/enhancer binding protein delta (C/EBP\{delta\}, CEBPD)-mediated nuclear import of FANCD2 by IPO4 augments cellular response to DNA damage. Proc Natl Acad Sci U S A. 2010; 107: 16131-6. doi:1002603107 [pii] 10.1073 /pnas.1002603107.

42. Matsushita N, Endo Y, Sato K, Kurumizaka H, Yamashita T, Takata M, et al. Direct inhibition of TNF-alpha promoter activity by Fanconi anemia protein FANCD2. PLoS One. 2011; 6: e23324. doi:10.1371/journal.pone.0023324.
43. Park E, Kim H, Kim JM, Primack B, Vidal-Cardenas S, Xu Y, et al. FANCD2 activates transcription of TAp63 and suppresses tumorigenesis. Mol Cell. 2013; 50: 908-18. doi:10.1016/j.molcel.2013.05.017.

44. Tanaka T, Yoshida N, Kishimoto T, Akira S. Defective adipocyte differentiation in mice lacking the C/EBPbeta and/or C/EBPdelta gene. Embo J. 1997; 16: 7432-43. doi:10.1093/emboj/16.24.7432.

45. Sterneck E, Paylor R, Jackson-Lewis V, Libbey M, Przedborski S, Tessarollo L, et al. Selectively enhanced contextual fear conditioning in mice lacking the transcriptional regulator CCAAT/enhancer binding protein delta. Proc Natl Acad Sci U S A. 1998; 95: 10908-13.

46. Takiguchi $\mathrm{M}$, Mori $\mathrm{M}$. In vitro analysis of the rat liver-type arginase promoter. J Biol Chem. 1991; 266: 9186-93.

47. Tang Y, Pacary E, Freret T, Divoux D, Petit E, Schumann-Bard P, et al. Effect of hypoxic preconditioning on brain genomic response before and following ischemia in the adult mouse: identification of potential neuroprotective candidates for stroke. Neurobiol Dis. 2006; 21: 18-28. doi:10.1016/j.nbd.2005.06.002.

48. Min Y, Ghose S, Boelte K, Li J, Yang L, Lin PC. C/EBP-delta regulates VEGF-C autocrine signaling in lymphangiogenesis and metastasis of lung cancer through HIF-1alpha. Oncogene. 2011; 30: 4901-9. doi:10.1038/onc.2011.187.

49. Wotton S, Terry A, Kilbey A, Jenkins A, Herzyk P, Cameron E, et al. Gene array analysis reveals a common Runx transcriptional programme controlling cell adhesion and survival. Oncogene. 2008; 27: 5856-66. doi:onc2008195 [pii] 10.1038/onc. 2008.195

50. Glaros T, Fu Y, Xing J, Li L. Molecular mechanism underlying persistent induction of LCN2 by lipopolysaccharide in kidney fibroblasts. PLoS One. 2012; 7: e34633. doi:10.1371/journal.pone.0034633.

51. Liu YW, Wang SA, Hsu TY, Chen TA, Chang WC, Hung JJ. Inhibition of LPS-induced C/EBP delta by trichostatin A has a positive effect on LPS-induced cyclooxygenase 2 expression in RAW264.7 cells. J Cell Biochem. 2010; 110: 1430-8. doi:10.1002/jcb.22682.

52. Borrelli S, Testoni B, Callari M, Alotto D, Castagnoli C, Romano RA, et al. Reciprocal regulation of $\mathrm{p} 63$ by $\mathrm{C} / \mathrm{EBP}$ delta in human keratinocytes. BMC Mol Biol. 2007; 8: 85. doi:10.1186/1471-2199-8-85.

53. Li B, Si J, DeWille JW. Ultraviolet radiation (UVR) activates p38 MAP kinase and induces post-transcriptional stabilization of the C/EBPdelta mRNA in G0 growth arrested mammary epithelial cells. J Cell Biochem. 2008; 103: 1657-69. doi:10.1002/jcb. 21554

54. Hsiao YW, Li CF, Chi JY, Tseng JT, Chang Y, Hsu LJ, et al. CCAAT/Enhancer Binding Protein delta in Macrophages Contributes to Immunosuppression and Inhibits Phagocytosis in Nasopharyngeal Carcinoma. Sci Signal. 2013; 6: ra59. doi:10.1126/scisignal.2003648

55. Banerjee S, Xie N, Cui H, Tan Z, Yang S, Icyuz M, et al. MicroRNA let-7c regulates macrophage polarization. J Immunol. 2013; 190: 6542-9. doi:10.4049/jimmunol.1202496.

56. Sarkar TR, Sharan S, Wang J, Pawar SA, Cantwell CA, Johnson PF, et al. Identification of a Src tyrosine kinase/SIAH2 E3 ubiquitin ligase pathway that regulates C/EBPdelta expression and contributes to transformation of breast tumor cells. Mol Cell Biol. 2012; 32: 320-32. doi:10.1128/mcb.05790-11.

57. Balamurugan K, Sharan S, Klarmann KD, Zhang Y, Coppola V, Summers GH, et al. FBXW7alpha attenuates inflammatory signalling by downregulating C/EBPdelta and its target gene Tlr4. Nature communications. 2013; 4: 1662. doi:10.1038/ncomms2677.

58. House CM, Moller A, Bowtell DD. Siah proteins: novel drug targets in the Ras and hypoxia pathways. Cancer Res. 2009; 69: 8835-8. doi:10.1158/0008-5472.can-09-1676.

59. Cheng Y, Li G. Role of the ubiquitin ligase Fbw7 in cancer progression. Cancer Metastasis Rev. 2012; 31: 75-87. doi:10.1007/s10555-011-9330-z.

60. Ji C, Chang W, Centrella M, McCarthy TL. Activation domains of CCAAT enhancer binding protein delta: regions required for native activity and prostaglandin E2-dependent transactivation of insulin-like growth factor I gene expression in rat osteoblasts. Mol Endocrinol. 2003; 17: 1834-43. doi:10.1210/me.2002-0235.

61. Kravchenko VV, Mathison JC, Schwamborn K, Mercurio F, Ulevitch RJ. IKKi/IKKepsilon plays a key role in integrating signals induced by pro-inflammatory stimuli. J Biol Chem. 2003; 278: 26612-9. doi:10.1074/jbc.M303001200.

62. Ray A, Ray BK. Serum amyloid A gene expression under acute-phase conditions involves participation of inducible C/EBP-beta and C/EBP-delta and their activation by phosphorylation. Mol Cell Biol. 1994; 14: 4324-32.

63. Yin M, Yang SQ, Lin HZ, Lane MD, Chatterjee S, Diehl AM. Tumor necrosis factor alpha promotes nuclear localization of cytokine-inducible CCAAT/enhancer binding protein isoforms in hepatocytes. J Biol Chem. 1996; 271: $17974-8$.

64. Billiard J, Umayahara Y, Wiren K, Centrella M, McCarthy TL, Rotwein P. Regulated nuclear-cytoplasmic localization of CCAAT/enhancer-binding protein delta in osteoblasts. J Biol Chem. 2001; 276: 15354-61. doi:10.1074/jbc.M009973200.

65. Kitami Y, Fukuoka T, Hiwada K, Inagami T. A high level of CCAAT-enhancer binding protein-delta expression is a major determinant for markedly elevated differential gene expression of the platelet-derived growth factor-alpha receptor in vascular smooth muscle cells of genetically hypertensive rats. Circ Res. 1999; 84: 64-73.

66. Fukuoka T, Kitami Y, Okura T, Hiwada K. Transcriptional regulation of the platelet-derived growth factor alpha receptor gene via 
CCAAT/enhancer-binding protein-delta in vascular smooth muscle cells. J Biol Chem. 1999; 274: 25576-82.

67. Zhou S, Si J, Liu T, DeWille JW. PIASy represses CCAAT/enhancer-binding protein delta (C/EBPdelta) transcriptional activity by sequestering C/EBPdelta to the nuclear periphery. J Biol Chem. 2008; 283: 20137-48. doi:10.1074/jbc.M801307200.

68. Tang QQ, Lane MD. Activation and centromeric localization of CCAAT/enhancer-binding proteins during the mitotic clonal expansion of adipocyte differentiation. Genes Dev. 1999; 13: 2231-41.

69. Billiard J, Grewal SS, Lukaesko L, Stork PJ, Rotwein P. Hormonal control of insulin-like growth factor I gene transcription in human osteoblasts: dual actions of cAMP-dependent protein kinase on CCAAT/enhancer-binding protein delta. J Biol Chem. 2001; 276: 31238-46. doi:10.1074/jbc.M103634200.

70. Thangaraju M, Rudelius M, Bierie B, Raffeld M, Sharan S, Hennighausen L, et al. C/EBPdelta is a crucial regulator of pro-apoptotic gene expression during mammary gland involution. Development. 2005; 132: 4675-85. doi:10.1242/dev.02050

71. Huang AM, Rudelius M, Sharan S, McAllister JM, Raffeld M, Christenson LK, et al. The Cebpd (C/EBPdelta) gene is induced by luteinizing hormones in ovarian theca and interstitial cells but is not essential for mouse ovary function. PLoS One. 2007; 2: e1334. doi:10.1371/journal.pone.0001334.

72. Milde-Langosch K, Loning T, Bamberger AM. Expression of the CCAAT/enhancer-binding proteins C/EBPalpha, C/EBPbeta and C/EBPdelta in breast cancer: correlations with clinicopathologic parameters and cell-cycle regulatory proteins. Breast Cancer Res Treat. 2003; 79: 175-85.

73. Barresi V, Vitarelli E, Cerasoli S, Barresi G. The cell growth inhibitory transcription factor C/EBPdelta is expressed in human meningiomas in association with low histological grade and proliferation index. J Neurooncol. 2010; 97: 233-40. doi:10.1007/s11060-009-0024-0.

74. Sugahara K, Sadohara T, Sugita M, Iyama K, Takiguchi M. Differential expression of CCAAT enhancer binding protein family in rat alveolar epithelial cell proliferation and in acute lung injury. Cell Tissue Res. 1999; 297: 261-70.

75. Duitman J, Hoogendijk AJ, Groot AP, Ruela de Sousa RR, van der Poll T, Florquin S, et al. CCAAT-enhancer binding protein delta (C/EBPdelta) protects against Klebsiella pneumoniae-induced pulmonary infection: potential role for macrophage migration. The Journal of infectious diseases. 2012; 206: 1826-35. doi:10.1093/infdis/jis615.

76. Johnson PF. Molecular stop signs: regulation of cell-cycle arrest by C/EBP transcription factors. Journal of cell science. 2005; 118: 2545-55. doi:10.1242/jcs.02459.

77. Jones LC, Lin ML, Chen SS, Krug U, Hofmann WK, Lee S, et al. Expression of $\mathrm{C} /$ EBPbeta from the C/ebpalpha gene locus is sufficient for normal hematopoiesis in vivo. Blood. 2002; 99: 2032-6.

78. Chiu CH, Lin WD, Huang SY, Lee YH. Effect of a C/EBP gene replacement on mitochondrial biogenesis in fat cells. Genes Dev. 2004; 18: 1970-5. doi:10.1101/gad.1213104.

79. Yan C, Zhu M, Staiger J, Johnson PF, Gao H. C5a-regulated CCAAT/enhancer binding protein beta and -delta are essential in Fcgamma receptor- mediated inflammatory cytokine and chemokine production in macrophages. J Biol Chem. 2012; 287: 3217-30. doi:10.1074/jbc.M111.280834.

80. Lu YC, Kim I, Lye E, Shen F, Suzuki N, Suzuki S, et al. Differential role for c-Rel and C/EBPbeta/delta in TLR-mediated induction of proinflammatory cytokines. J Immunol. 2009; 182: 7212-21. doi:10.4049/jimmunol.0802971.

81. Staiger J, Lueben MJ, Berrigan D, Malik R, Perkins SN, Hursting SD, et al. $\mathrm{C} /$ EBPbeta regulates body composition, energy balance-related hormones and tumor growth. Carcinogenesis. 2009; 30: 832-40. doi:10.1093/carcin/bgn273.

82. Yan C, Johnson PF, Tang H, Ye Y, Wu M, Gao H. CCAAT/Enhancer-Binding Protein delta Is a Critical Mediator of Lipopolysaccharide-Induced Acute Lung Injury. The American journal of pathology. 2012. doi:10.1016/j.ajpath.2012.10.013.

83. Yan $\mathrm{C}, \mathrm{Wu} \mathrm{M}, \mathrm{Cao} J$, Tang $\mathrm{H}$, Zhu M, Johnson PF, et al. Critical role for CCAAT/enhancer-binding protein beta in immune complex-induced acute lung injury. J Immunol. 2012; 189: 1480-90. doi:10.4049/jimmunol.1200877.

84. Yang L, Jiang $\mathrm{Y}$, Wu SF, Zhou MY, Wu YL, Chen GQ. CCAAT/enhancer-binding protein alpha antagonizes transcriptional activity of hypoxia-inducible factor 1 alpha with direct protein-protein interaction. Carcinogenesis. 2008; 29: 291-8. doi:10.1093/carcin/bgm262.

85. O'Rourke JP, Newbound GC, Hutt JA, DeWille J. CCAAT/enhancer-binding protein delta regulates mammary epithelial cell G0 growth arrest and apoptosis. J Biol Chem. 1999; 274: 16582-9.

86. Dearth LR, DeWille J. Posttranscriptional and posttranslational regulation of C/EBP delta in G0 growth-arrested mammary epithelial cells. J Biol Chem. 2003; 278: 11246-55. doi:10.1074/jbc.M207930200.

87. Huang AM, Montagna C, Sharan S, Ni Y, Ried T, Sterneck E. Loss of CCAAT/enhancer binding protein delta promotes chromosomal instability. Oncogene. 2004; 23: 1549-57. doi:10.1038/sj.onc.1207285.

88. Hutt JA, DeWille JW. Oncostatin $M$ induces growth arrest of mammary epithelium via a CCAAT/enhancer-binding protein delta-dependent pathway. Mol Cancer Ther. 2002; 1: 601-10.

89. Pawar SA, Roy Sarkar T, Balamurugan K, Sharan S, Wang J, Zhang Y, et al. $\mathrm{C} / \mathrm{EBP}\{$ delta\} targets cyclin D1 for proteasome-mediated degradation via induction of CDC27/APC3 expression. Proc Natl Acad Sci U S A. 2010; 107: 9210-5. doi:0913813107 [pii] 10.1073/pnas.0913813107.
90. Gigliotti AP, Johnson PF, Sterneck E, DeWille JW. Nulliparous CCAAT/enhancer binding proteindelta (C/EBPdelta) knockout mice exhibit mammary gland ductal hyperlasia. Exp Biol Med (Maywood). 2003; 228: 278-85.

91. Gery S, Tanosaki S, Hofmann WK, Koppel A, Koeffler HP. C/EBPdelta expression in a BCR-ABL-positive cell line induces growth arrest and myeloid differentiation. Oncogene. 2005; 24: 1589-97. doi:1208393 [pii] 10.1038/sj.onc. 1208393

92. Sanford DC, DeWille JW. C/EBPdelta is a downstream mediator of IL-6 induced growth inhibition of prostate cancer cells. Prostate. 2005; 63: 143-54. doi:10.1002/pros.20159.

93. Ikezoe T, Gery S, Yin D, O'Kelly J, Binderup L, Lemp N, et al. CCAAT/enhancer-binding protein delta: a molecular target of 1,25-dihydroxyvitamin D3 in androgen-responsive prostate cancer LNCaP cells. Cancer Res. 2005; 65: 4762-8. doi:10.1158/0008-5472.CAN-03-3619.

94. Yang G, Gregory CW, Shang Q, O'Brien DA, Zhang YL. Differential expression of CCAAT/enhancer-binding protein-delta (c/EBPdelta) in rat androgen-dependent tissues and human prostate cancer. J Androl. 2001; 22: 471-80.

95. Umayahara $\mathrm{Y}$, Ji $\mathrm{C}$, Centrella $\mathrm{M}$, Rotwein $\mathrm{P}$, McCarthy TL. CCAAT/enhancer-binding protein delta activates insulin-like growth factor-I gene transcription in osteoblasts. Identification of a novel cyclic AMP signaling pathway in bone. J Biol Chem. 1997; 272: 31793-800.

96. Hishida T, Nishizuka M, Osada S, Imagawa M. The role of C/EBPdelta in the early stages of adipogenesis. Biochimie. 2009; 91: 654-7. doi:10.1016/j.biochi.2009.02.002.

97. Siersbaek R, Nielsen R, John S, Sung MH, Baek S, Loft A, et al. Extensive chromatin remodelling and establishment of transcription factor 'hotspots' during early adipogenesis. Embo J. 2011; 30: 1459-72. doi:10.1038/emboj.2011.65.

98. Chen PL, Riley DJ, Chen YM, Lee WH. Retinoblastoma protein positively regulates terminal adipocyte differentiation through direct interaction with C/EBPs. Genes \& Development. 1996; 10: 2794-804. doi:Doi 10.1101/Gad.10.21.2794.

99. Pan YC, Li CF, Ko CY, Pan MH, Chen PJ, Tseng JT, et al. CEBPD reverses RB/E2F1-mediated gene repression and participates in HMDB-induced apoptosis of cancer cells. Clin Cancer Res. 2010; 16: 5770-80. doi:10.1158/1078-0432.CCR-10-1025.

100. Radich JP, Dai H, Mao M, Oehler V, Schelter J, Druker B, et al. Gene expression changes associated with progression and response in chronic myeloid leukemia. Proc Natl Acad Sci U S A. 2006; 103: 2794-9. doi:10.1073/pnas.0510423103.

101. Wang QF, Friedman AD. CCAAT/enhancer-binding proteins are required for granulopoiesis independent of their induction of the granulocyte colony-stimulating factor receptor. Blood. 2002; 99: 2776-85.

102. Scott LM, Civin CI, Rorth P, Friedman AD. A novel temporal expression pattern of three C/EBP family members in differentiating myelomonocytic cells. Blood. 1992; 80: 1725-35.

103. Barbaro V, Testa A, Di Iorio E, Mavilio F, Pellegrini G, De Luca M. C/EBPdelta regulates cell cycle and self-renewal of human limbal stem cells. J Cell Biol. 2007; 177: 1037-49. doi:jcb.200703003 [pii] 10.1083/jcb.200703003.

104. Wright LS, Li J, Caldwell MA, Wallace K, Johnson JA, Svendsen CN. Gene expression in human neural stem cells: effects of leukemia inhibitory factor. Journal of neurochemistry. 2003; 86: 179-95.

105. Buckley SM, Aranda-Orgilles B, Strikoudis A, Apostolou E, Loizou E, Moran-Crusio K, et al. Regulation of pluripotency and cellular reprogramming by the ubiquitin-proteasome system. Cell Stem Cell. 2012; 11: 783-98. doi:10.1016/j.stem.2012.09.011.

106. Wang Z, Inuzuka H, Fukushima H, Wan L, Gao D, Shaik S, et al. Emerging roles of the FBW7 tumour suppressor in stem cell differentiation. EMBO Rep. 2012; 13: 36-43. doi:10.1038/embor.2011.231.

107. Takeishi S, Matsumoto A, Onoyama I, Naka K, Hirao A, Nakayama KI. Ablation of Fbxw7 eliminates leukemia-initiating cells by preventing quiescence. Cancer cell. 2013; 23: 347-61. doi:10.1016/j.ccr.2013.01.026.

108. Porter DA, Krop IE, Nasser S, Sgroi D, Kaelin CM, Marks JR, et al. A SAGE (serial analysis of gene expression) view of breast tumor progression. Cancer Res. 2001; 61: 5697-702.

109. Chapman RS, Lourenco PC, Tonner E, Flint DJ, Selbert S, Takeda K, et al. Suppression of epithelial apoptosis and delayed mammary gland involution in mice with a conditional knockout of Stat3. Genes Dev. 1999; 13: 2604-16.

110. Resemann HK, Watson CJ, Lloyd-Lewis B. The Stat3 paradox: A killer and an oncogene. Molecular and cellular endocrinology. 2013. doi:10.1016/j.mce.2013.06.029.

111. Ranger JJ, Levy DE, Shahalizadeh S, Hallett M, Muller WJ. Identification of a Stat3-dependent transcription regulatory network involved in metastatic $\begin{array}{lllll}\text { progression. } & \text { Cancer } & \text { Res. 2009; 69: } & \text { 6823-30. }\end{array}$ doi:10.1158/0008-5472.CAN-09-1684.

112. Moore F, Santin I, Nogueira TC, Gurzov EN, Marselli L, Marchetti P, et al. The transcription factor C/EBP delta has anti-apoptotic and anti-inflammatory roles in pancreatic beta cells. PLoS One. 2012; 7: e31062. doi:10.1371/journal.pone.0031062.

113. Hour TC, Lai YL, Kuan CI, Chou CK, Wang JM, Tu HY, et al. Transcriptional up-regulation of SOD1 by CEBPD: A potential target for cisplatin resistant human urothelial carcinoma cells. Biochem Pharmacol. 2010; 80: 325-34. doi:S0006-2952(10)00252-2 [pii] 10.1016/j.bcp.2010.04.007. 
114. Wu SR, Li CF, Hung LY, Huang AM, Tseng JT, Tsou JH, et al. CCAAT/enhancer-binding protein delta mediates tumor necrosis factor alpha-induced Aurora kinase $\mathrm{C}$ transcription and promotes genomic instability. J Biol Chem. 2011; 286: 28662-70. doi:10.1074/jbc.M111.270710.

115. Huber R, Pietsch D, Panterodt T, Brand K. Regulation of C/EBPbeta and resulting functions in cells of the monocytic lineage. Cellular signalling. 2012; 24: 1287-96. doi:10.1016/j.cellsig.2012.02.007.

116. Akagi T, Thoennissen NH, George A, Crooks G, Song JH, Okamoto R, et al. In vivo deficiency of both $\mathrm{C} / \mathrm{EBP}$ beta and $\mathrm{C} / \mathrm{EBP}$ epsilon results in highly defective myeloid differentiation and lack of cytokine response. PLoS One. 2010; 5: e15419. doi:10.1371/journal.pone.0015419.

117. Kawai T, Akira S. Toll-like receptors and their crosstalk with other innate receptors in infection and immunity. Immunity. 2011; 34: 637-50. doi:10.1016/j.immuni.2011.05.006.

118. Maitra U, Gan L, Chang S, Li L. Low-Dose Endotoxin Induces Inflammation by Selectively Removing Nuclear Receptors and Activating CCAAT/Enhancer-Binding Protein \{delta\}. J Immunol. 2011; 186: 4467-73. doi:10.4049/jimmunol.1003300.

119. Yan C, Ward PA, Wang X, Gao H. Myeloid depletion of SOCS3 enhances LPS-induced acute lung injury through CCAAT/enhancer binding protein delta pathway. FASEB journal : official publication of the Federation of American Societies for Experimental Biology. 2013; 27: 2967-76. doi:10.1096/fj.12-225797.

120. Duitman J, Schouten M, Groot AP, Daalhuisen JB, Florquin S, van der Poll T, et al. CCAAT/enhancer-binding protein delta facilitates bacterial dissemination during pneumococcal pneumonia in a platelet-activating factor receptor-dependent manner. Proc Natl Acad Sci U S A. 2012; 109: 9113-8. doi:10.1073/pnas.1202641109.

121. Goldszmid RS, Trinchieri G. The price of immunity. Nat Immunol. 2012; 13: 932-8. doi:10.1038/ni.2422

122. Slofstra SH, Groot AP, Obdeijn MH, Reitsma PH, ten Cate H, Spek CA. Gene expression profiling identifies C/EBPdelta as a candidate regulator of endotoxin-induced disseminated intravascular coagulation. Am J Respir Crit Care Med. 2007; 176: 602-9. doi:10.1164/rccm.200609-1250OC

123. Poli V. The role of C/EBP isoforms in the control of inflammatory and native immunity functions. J Biol Chem. 1998; 273: 29279-82.

124. Li R, Strohmeyer R, Liang Z, Lue LF, Rogers J. CCAAT/enhancer binding protein delta (C/EBPdelta) expression and elevation in Alzheimer's disease. $\begin{array}{llll}\text { Neurobiology of 2004; } & \text { 25: }\end{array}$ doi:10.1016/j.neurobiolaging.2003.10.016.

125. Ko CY, Chang LH, Lee YC, Sterneck E, Cheng CP, Chen SH, et al. CCAAT/enhancer binding protein delta (CEBPD) elevating PTX3 expression inhibits macrophage-mediated phagocytosis of dying neuron cells. Neurobiology of aging. 2012; 33: 422.e11-25. doi:10.1016/j.neurobiolaging.2010.09.017.

126. Tsai VW, Mohammad MG, Tolhurst O, Breit SN, Sawchenko PE, Brown DA. CCAAT/enhancer binding protein-delta expression by dendritic cells regulates CNS autoimmune inflammatory disease. The Journal of neuroscience : the official journal of the Society for Neuroscience. 2011; 31: 17612-21. doi:10.1523/JNEUROSCI.3449-11.2011.

127. Valente T, Straccia M, Gresa-Arribas N, Dentesano G, Tusell JM, Serratosa J, et al. CCAAT/enhancer binding protein delta regulates glial proinflammatory gene expression. Neurobiology of aging. 2013; 34: 2110-24. doi:10.1016/j.neurobiolaging.2013.02.007.

128. Gresa-Arribas N, Serratosa J, Saura J, Sola C. Inhibition of CCAAT/enhancer binding protein delta expression by chrysin in microglial cells results in anti-inflammatory and neuroprotective effects. Journal of neurochemistry. 2010; 115: 526-36. doi:10.1111/j.1471-4159.2010.06952.x.

129. Chang LH, Huang HS, Wu PT, Jou IM, Pan MH, Chang WC, et al. Role of macrophage CCAAT/enhancer binding protein delta in the pathogenesis of rheumatoid arthritis in collagen-induced arthritic mice. PLoS One. 2012; 7 : e45378. doi:10.1371/journal.pone.0045378.

130. Massaad C, Paradon M, Jacques C, Salvat C, Bereziat G, Berenbaum F, et al. Induction of secreted type IIA phospholipase A2 gene transcription by interleukin-1beta. Role of C/EBP factors. J Biol Chem. 2000; 275: 22686-94. doi:10.1074/jbc.M001250200.

131. Sai S, Esteves CL, Kelly V, Michailidou Z, Anderson K, Coll AP, et al. Glucocorticoid regulation of the promoter of 11beta-hydroxysteroid dehydrogenase type 1 is indirect and requires CCAAT/enhancer-binding protein-beta. Mol Endocrinol. 2008; 22: 2049-60. doi:10.1210/me.2007-0489.

132. Allen DL, Cleary AS, Hanson AM, Lindsay SF, Reed JM. CCAAT/enhancer binding protein-delta expression is increased in fast skeletal muscle by food deprivation and regulates myostatin transcription in vitro. American journal of physiology Regulatory, integrative and comparative physiology. 2010; 299: R1592-601. doi:10.1152/ajpregu.00247.2010.

133. Liu YW, Tseng HP, Chen LC, Chen BK, Chang WC. Functional cooperation of simian virus 40 promoter factor 1 and CCAAT/enhancer-binding protein beta and delta in lipopolysaccharide-induced gene activation of IL-10 in mouse macrophages. J Immunol. 2003; 171: 821-8.

134. Si J, Yu X, Zhang Y, DeWille JW. Myc interacts with Max and Miz1 to repress C/EBPdelta promoter activity and gene expression. Mol Cancer. 2010; 9: 92. doi:10.1186/1476-4598-9-92.

135. Do-Umehara HC, Chen C, Urich D, Zhou L, Qiu J, Jang S, et al. Suppression of inflammation and acute lung injury by Miz1 via repression of C/EBP-delta. Nat Immunol. 2013; 14: 461-9. doi:10.1038/ni.2566.
136. Takata Y, Kitami Y, Yang ZH, Nakamura M, Okura T, Hiwada K. Vascular inflammation is negatively autoregulated by interaction between CCAAT/enhancer-binding protein-delta and peroxisome proliferator-activated receptor-gamma. Circ Res. 2002; 91: 427-33.

137. Kaundal RK, Sharma SS. Peroxisome proliferator-activated receptor gamma agonists as neuroprotective agents. Drug news \& perspectives. 2010; 23: 241-56. doi:10.1358/dnp.2010.23.4.1437710.

138. Klamer G, Song E, Ko KH, O'Brien TA, Dolnikov A. Using small molecule GSK3beta inhibitors to treat inflammation. Current medicinal chemistry. 2010; 17: 2873-81.

139. Porter D, Lahti-Domenici J, Keshaviah A, Bae YK, Argani P, Marks J, et al. Molecular markers in ductal carcinoma in situ of the breast. Mol Cancer Res. 2003; 1 : 362-75.

140. Zucchi I, Mento E, Kuznetsov VA, Scotti M, Valsecchi V, Simionati B, et al. Gene expression profiles of epithelial cells microscopically isolated from a breast-invasive ductal carcinoma and a nodal metastasis. Proc Natl Acad Sci U S A. 2004; 101: 18147-52. doi:10.1073/pnas.0408260101.

141. Naderi A, Teschendorff AE, Barbosa-Morais NL, Pinder SE, Green AR, Powe $\mathrm{DG}$, et al. A gene-expression signature to predict survival in breast cancer across independent data sets. Oncogene. 2007; 26: 1507-16. doi:10.1038/sj.onc.1209920.

142. Ko CY, Hsu HC, Shen MR, Chang WC, Wang JM. Epigenetic silencing of CCAAT/enhancer-binding protein delta activity by YY1/polycomb group/DNA methyltransferase complex. J Biol Chem. 2008; 283: 30919-32. doi:10.1074/jbc.M804029200.

143. Tang D, Sivko GS, DeWille JW. Promoter methylation reduces C/EBPdelta (CEBPD) gene expression in the SUM-52PE human breast cancer cell line and in primary breast tumors. Breast Cancer Res Treat. 2005; 95: 161-70. doi:10.1007/s10549-005-9061-3.

144. Palmieri C, Monteverde M, Lattanzio L, Gojis O, Rudraraju B, Fortunato M, et al. Site-specific CpG methylation in the CCAAT/enhancer binding protein delta (CEBPdelta) CpG island in breast cancer is associated with metastatic relapse. Br J Cancer. 2012; 107: 732-8. doi:10.1038/bjc.2012.308.

145. Ceccarelli V, Racanicchi S, Martelli MP, Nocentini G, Fettucciari K, Riccardi C, et al. Eicosapentaenoic acid demethylates a single CpG that mediates expression of tumor suppressor CCAAT/enhancer-binding protein delta in U937 leukemia cells. J Biol Chem. 2011; 286: 27092-102. doi:10.1074/jbc.M111.253609.

146. Brueckner LM, Hess EM, Schwab M, Savelyeva L. Instability at the FRA8I common fragile site disrupts the genomic integrity of the KIAA0146, CEBPD and PRKDC genes in colorectal cancer. Cancer Lett. 2013; 336: 85-95. doi:10.1016/j.canlet.2013.04.007.

147. Tang D, DeWille J. Detection of base sequence changes in the CEBPD gene in human breast cancer cell lines and primary breast cancer isolates. Mol Cell Probes. 2003; 17: 11-4.

148. Vegesna V, Takeuchi S, Hofmann WK, Ikezoe T, Tavor S, Krug U, et al. C/EBP-beta, C/EBP-delta, PU.1, AML1 genes: mutational analysis in 381 samples of hematopoietic and solid malignancies. Leuk Res. 2002; 26: 451-7.

149. Bennett CE, Nsengimana J, Bostock JA, Cymbalista C, Futers TS, Knight BL, et al. CCAAT/enhancer binding protein alpha, beta and delta gene variants: associations with obesity related phenotypes in the Leeds Family Study. Diab Vasc Dis Res. 2010; 7: 195-203. doi:10.1177/1479164110366274.

150. Angeloni D, Lee JD, Johnson BE, Teh BT, Dean M, Lerman MI, et al. C306A single nucleotide polymorphism in the human CEBPD gene that maps at 8p11.1-p11.2. Molecular and Cellular Probes. 2001; 15: 395-7. doi:Doi 10.1006/Mcpr.2001.0377.

151. Tong Y, Zheng Y, Zhou J, Oyesiku NM, Koeffler HP, Melmed S. Genomic characterization of human and rat prolactinomas. Endocrinology. 2012; 153. 3679-91. doi:10.1210/en.2012-1056.

152. Covell DG, Wallqvist A, Rabow AA, Thanki N. Molecular classification of cancer: unsupervised self-organizing map analysis of gene expression microarray data. Mol Cancer Ther. 2003; 2: 317-32.

153. Willenbrock K, Kuppers R, Renne C, Brune V, Eckerle S, Weidmann E, et al. Common features and differences in the transcriptome of large cell anaplastic lymphoma and classical Hodgkin's lymphoma. Haematologica. 2006; 91: 596-604

154. Carro MS, Lim WK, Alvarez MJ, Bollo RJ, Zhao X, Snyder EY, et al. The transcriptional network for mesenchymal transformation of brain tumours. Nature. 2010; 463: 318-25. doi:10.1038/nature08712.

155. Hagedorn M, Delugin M, Abraldes I, Allain N, Belaud-Rotureau MA, Turmo $\mathrm{M}$, et al. FBXW7/hCDC4 controls glioma cell proliferation in vitro and is a prognostic marker for survival in glioblastoma patients. Cell Div. 2007; 2 : 9. doi:10.1186/1747-1028-2-9.

156. Shay JE, Celeste Simon M. Hypoxia-inducible factors: crosstalk between inflammation and metabolism. Seminars in cell \& developmental biology. 2012; 23: 389-94. doi:10.1016/j.semcdb.2012.04.004.

157. Trinchieri G. Cancer and inflammation: an old intuition with rapidly evolving new concepts. Annual review of immunology. 2012; 30: 677-706. doi:10.1146/annurev-immunol-020711-075008

158. Semenza GL. Hypoxia-inducible factors: mediators of cancer progression and targets for cancer therapy. Trends in pharmacological sciences. 2012; 33: 207-14. doi:10.1016/j.tips.2012.01.005.

159. Semenza GL. Targeting HIF-1 for cancer therapy. Nat Rev Cancer. 2003; 3: 721-32. doi:10.1038/nrc1187. 
160. Greijer AE, van der Wall E. The role of hypoxia inducible factor 1 (HIF-1) in hypoxia induced apoptosis. J Clin Pathol. 2004; 57: 1009-14. doi:10.1136/jcp.2003.015032.

161. Bosco MC, Puppo M, Blengio F, Fraone T, Cappello P, Giovarelli M, et al. Monocytes and dendritic cells in a hypoxic environment: Spotlights on chemotaxis and migration. Immunobiology. 2008; 213: 733-49. doi:10.1016/j.imbio.2008.07.031.

162. Feinberg MW, Watanabe M, Lebedeva MA, Depina AS, Hanai J, Mammoto T, et al. Transforming growth factor-beta1 inhibition of vascular smooth muscle cell activation is mediated via Smad3. J Biol Chem. 2004; 279: 16388-93. doi:10.1074/jbc.M309664200.

163. de Heredia LL, Magoulas C. Lack of the transcription factor C/EBPdelta impairs the intrinsic capacity of peripheral neurons for regeneration. Exp Neurol. 2012. doi:10.1016/j.expneurol.2012.10.012.

164. Chang LH, Huang HS, Wu PT, Jou IM, Pan MH, Chang WC, et al. Role of Macrophage CCAAT/Enhancer Binding Protein Delta in the Pathogenesis of Rheumatoid Arthritis in Collagen-Induced Arthritic Mice. PLoS ONE 2012; 7:e45378.

165. Thangaraju M, Ananth S, Martin PM, Roon P, Smith SB, Sterneck E, et al. c/ebpdelta Null mouse as a model for the double knock-out of slc5a8 and slc5a12 in kidney. J Biol Chem. 2006; 281: 26769-73. doi:C600189200 [pii] 10.1074/jbc.C600189200.

166. Takeji M, Kawada N, Moriyama T, Nagatoya K, Oseto S, Akira S, et al. CCAAT/Enhancer-binding protein delta contributes to myofibroblast transdifferentiation and renal disease progression. J Am Soc Nephrol. 2004; 15: 2383-90. doi:10.1097/01.ASN.0000136426.01160.2F.

167. Wang JM, Tseng JT, Chang WC. Induction of human NF-IL6beta by epidermal growth factor is mediated through the p38 signaling pathway and cAMP response element-binding protein activation in A431 cells. Mol Biol Cell. 2005; 16: 3365-76. doi:10.1091/mbc.E05-02-0105.

168. Chen H, Libertini SJ, George M, Dandekar S, Tepper CG, Al-Bataina B, et al. Genome-wide analysis of androgen receptor binding and gene regulation in two CWR22-derived prostate cancer cell lines. Endocrine-related cancer. 2010; 17: 857-73. doi:10.1677/ERC-10-0081.

169. Khan JA, Bellance C, Guiochon-Mantel A, Lombes M, Loosfelt H. Differential regulation of breast cancer-associated genes by progesterone receptor isoforms PRA and PRB in a new bi-inducible breast cancer cell line. PLoS One. 2012; 7: e45993. doi:10.1371/journal.pone.0045993.

170. Ali S, Singh NN, Yildirim H, Ramji DP. Requirement for nuclear factor kappa B signalling in the interleukin-1-induced expression of the CCAAT/enhancer binding protein-delta gene in hepatocytes. The international journal of biochemistry \& cell biology. 2010; 42: 113-9. doi:10.1016/j.biocel.2009.09.018.

171. Cantwell CA, Sterneck E, Johnson PF. Interleukin-6-specific activation of the C/EBPdelta gene in hepatocytes is mediated by Stat3 and Sp1. Mol Cell Biol. 1998; 18: 2108-17.

172. Sekine O, Nishio Y, Egawa K, Nakamura T, Maegawa H, Kashiwagi A. Insulin activates CCAAT/enhancer binding proteins and proinflammatory gene expression through the phosphatidylinositol 3-kinase pathway in vascular smooth muscle cells. J Biol Chem. 2002; 277: 36631-9. doi:10.1074/jbc.M206266200.

173. Hallenborg P, Feddersen S, Francoz S, Murano I, Sundekilde U, Petersen RK, et al. Mdm2 controls CREB-dependent transactivation and initiation of adipocyte differentiation. Cell death and differentiation. 2012; 19: 1381-9. doi:10.1038/cdd.2012.15.

174. Cardinaux JR, Magistretti PJ. Vasoactive intestinal peptide, pituitary adenylate cyclase-activating peptide, and noradrenaline induce the transcription factors CCAAT/enhancer binding protein (C/EBP)-beta and C/EBP delta in mouse cortical astrocytes: involvement in cAMP-regulated glycogen metabolism. The Journal of neuroscience : the official journal of the Society for Neuroscience. 1996; 16: 919-29.

175. Borges TJ, Lopes RL, Pinho NG, Machado FD, Souza AP, Bonorino C Extracellular Hsp70 inhibits pro-inflammatory cytokine production by IL-10 driven down-regulation of C/EBPbeta and C/EBPdelta. Int J Hyperthermia. 2013; 29: 455-63. doi:10.3109/02656736.2013.798037.

176. Wang Y, Sul HS. Pref-1 regulates mesenchymal cell commitment and differentiation through Sox9. Cell metabolism. 2009; 9: 287-302. doi:10.1016/j.cmet.2009.01.013.

177. Zhang $\mathrm{K}$, Wang $\mathrm{S}$, Malhotra J, Hassler JR, Back SH, Wang $\mathrm{G}$, et al. The unfolded protein response transducer IRE1alpha prevents ER stress-induced hepatic steatosis. Embo J. 2011; 30: 1357-75. doi:10.1038/emboj.2011.52.

178. Svotelis A, Doyon G, Bernatchez G, Desilets A, Rivard N, Asselin C IL-1 beta-dependent regulation of C/EBP delta transcriptional activity. Biochem Biophys Res Commun. 2005; 328: 461-70. doi:10.1016/j.bbrc.2005.01.002. 